\title{
Waste Heat Recycling for Fuel Reforming
}

\author{
Rong-Fang Horng ${ }^{1}$ and Ming-Pin Lai ${ }^{2}$ \\ ${ }^{1}$ Department of Mechanical Engineering, \\ Kun Shan University, Tainan City, \\ ${ }^{2}$ Department of Aeronautics and Astronautics, \\ National Cheng Kung University, Tainan City,
}

Taiwan

\section{Introduction}

At the current rate of consumption, it is estimated that the crude oil reserves of the entire world will be depleted in less than 40 years. Due to an unstable international situation, the price of crude oil keeps rising, compelling the price of other fossil energies to soar. Because of its high dependency on imported energy, Taiwan is deeply affected by the crude oil price. Additionally, because of its low cost and high carbon number, fossil fuel has been the major fuel used in Taiwan. The enormous number of vehicles and motorcycles in Taiwan emit excess amounts of carbon dioxide, sulfur, and nitrogen; consequently, the level of greenhouse gas emissions in Taiwan far exceeds that of other countries. Because coal, natural gas, and petroleum will still be the major sources of energy in the short to medium term future; and since increasing energy efficiency is presently a globally acknowledged strategy; the use of new energy technologies for the transformation of traditional fuels into clean fuels - such as clean coal, fuel cells, and fuel reforming - is being promoted all over the world. Combining all the factors described, it has become necessary to quickly develop new energy and combustion techniques with existing equipment and resources to reduce air pollution produced by combustion.

Plasma-assisted reforming of hydrogen production is a promising energy utilization technology, and an increasing number of research units are conducting related experiments around the world. Plasma-assisted production of hydrogen is different from traditional hydrogen production approaches, and the equipment involved in the plasma-assisted production of hydrogen is small, easy to start, and economical; it can also increase overall thermal efficiency of internal combustion engine by combining with the hydrogen produced from the fuel reforming system.

The method of hydrogen production by plasma or catalytic converters with various hydrocarbon fuels has been studied by various researchers internationally. An arc generated plasma was used to facilitate the reforming reaction by heating. The heated mixture could be distributed to all of the passages in the reaction chamber by arc rotation driven by magnetic field. Water vapor could be directed into the system to lower the temperature of the electrodes via heat recycling to prevent the reaction region from over-heating, therefore extending the life of the system (Bromberg et al., 1997). The optimum settings and the cost of 
a plasma-catalyst natural gas reformer were analyzed. Preliminary results showed that the specific energy consumption of a small scale plasma reformer can be effectively reduced through efficient thermal management and heat recycling (Bromberg et al., 2000). The characteristics of hydrogen production from isooctane were studied and reported that hydrogen yield at catalyst temperatures as high as $800^{\circ} \mathrm{C}$ was significantly improved by using a combined plasma/catalytic system (Sobacchi et al., 2002). Some researchers investigated autothermal reforming of methane and propane by $2 \mathrm{wt} \%$-catalysts on alumina support. They proposed the activity level of the catalysts in descending order as: $\mathrm{Rh}>\mathrm{Pd}>$ $\mathrm{Ni}>\mathrm{Pt}>\mathrm{Co}$. They demonstrated that high activity was achieved by loading suitable amount of $\mathrm{Ni}$, while under the same loading, activity was higher for the Rh-based catalyst (Ayabe et al., 2003). A plasma catalytic reactor was employed for the combined oxygensteam reforming of methane. It was found that by combining the dielectric barrier discharge (DBD) and a Ni catalyst the conversion of methane was not improved, but complete conversion of oxygen was achieved. Under a suitable temperature to maintain the $\mathrm{Ni}$ catalytically active, the product selectivities changed significantly (Pietruszka \& Heintze, 2004). Preparation of intake mixture for reforming performance was investigated. It showed that feeding fuel via an intake swirl significantly facilitated the conversion efficiency of methane, and elevated the concentration of hydrogen. Both higher arc frequencies and longer retention time improving hydrogen concentration were also confirmed (Horng et al., 2007). The plasma converter on hydrogen production via methane reforming and the carbon deposit growth on the electrode surface were explored, and the microstructure of carbon was analyzed with scanning electron microscopy (SEM) and micro-Raman spectroscopy (Horng et al., 2006a). The reforming of aliphatic hydrocarbon such as methane, propane and neopentane, using non-thermal plasma was carried out. It demonstrated that reforming by combining carbon dioxide with methane and propane, yielded a higher $\mathrm{H}_{2} / \mathrm{CO}$ ratio than using neopentane. When using steam reforming, methane yielded the highest $\mathrm{H}_{2} / \mathrm{CO}$ ratio (Futamura et al., 2006). The literature on the field of hydrogen production assisted by nonthermal plasma reforming was reviewed by a group of researchers. They concluded that most of the existing reforming reactors were still being developed and advanced in research laboratories (Petitpas et al., 2007). The Tokyo Institute of Technology studied the plasma and the glid-arc reforming approaches and found that both of them required high temperature to produce hydrogen. In contrast, the dielectric barrier discharge (DBD) reforming approach could produce hydrogen at lower temperatures (between 400 and $600{ }^{\circ} \mathrm{C}$ ) by adding water vapor in fuel (Nozaki \& Okazaki, 2005).

Concerning the heat regeneration, a high energy level of thermal plasma to accelerate the reforming reaction was studied. It was suggested that the methods of heat insulation, heat regeneration and improved plasma catalysis could reduce the energy loss and improve methane conversion efficiency (Bromberg et al., 1999b). The utilization of phase change material (PCM) for heat-recovery was experimentally studied. Copper balls as the PCM were encapsulated by nickel film with/without an insertion of carbon or ruthenium as an inhibition layer. The results showed that the copper PCM with the thick film of nickel and an inactive layer between nickel and copper was available for producing hydrogen by hightemperature waste heat recovery (Maruoka et al., 2002). A high temperature plasma technique was applied on the reforming of methane or other hydrocarbon fuels to produce hydrogen-rich gas. To reduce energy loss and to increase methane conversion, heat could be insulated and exchanged at the plasma converter. Thermal efficiency of partial oxidation 
reforming using external heating from the perspective of thermodynamics was studied. It was revealed that higher $\mathrm{O} / \mathrm{C}$ ratios resulted in low thermal efficiency as a significant amount of fuel was found to be oxidated in the reforming process (Lutz et al., 2004). The reforming of exhaust gas recirculation (EGR) for producing $\mathrm{H}_{2}$ and $\mathrm{CO}$ was studied. By adding the contents of $\mathrm{H}_{2}$ and $\mathrm{CO}$, the in-cylinder premixed combustion of engine would be enhanced; and then a super lean burn process, low NOx operations could be achieved (Zheng et al., 2004). A numerical simulation on the technique of pure external heating and the method of reusing partial oxidation produced through external heating of hydrogen were used for investigating thermal efficiency. The former was found to be of higher efficiency, which was enhanced with increasing $\mathrm{H}_{2} \mathrm{O}$ /Carbon ratio (Lutz et al., 2003). A small scale hydrogen producing system was designed with utilizing heat exchange to heat up the vapourising unit. The reforming thermal efficiency attained was as high as $78 \%$ while the methane conversion efficiency was $89 \%$, capable of supplying a $1 \mathrm{~kW}$ fuel cell (Seo et al., 2006). Dimethyl ether (DME) and methanol-reformed gas (MRG) were produced from methanol by onboard reformers utilising the exhaust heat from the engine. Because the reactions producing DME and MRG are endothermic, a part of exhaust heat energy can be recovered during the fuel reforming process. This research experimentally investigated characteristics of combustion, exhaust emissions, engine efficiency and overall thermal efficiency including the waste heat recovery through the fuel reforming in the HCCI combustion engine system (Shudo, 2006). Tri-reforming of natural gas using flue gas from power plants with the combination of heat transfer or heat exchange including reactor heat up and waste heat utilization was studied. The tri-reforming process could be applied to the production of synthetic gas by reforming of natural gas using gas mixtures (containing $\mathrm{CO}_{2}$, $\mathrm{H}_{2} \mathrm{O}$, and $\mathrm{O}_{2}$ ) as co-feeds. As a result, the mitigation of $\mathrm{CO}_{2}$ could be achieved by waste heat recovery. However, various strategic considerations, technical approaches, and specific research directions have been presented. More research is necessary towards effective $\mathrm{CO}_{2}$ conversion into useful substances using renewable sources of energy (Song, 2006). The hydrogen production from low carbon fuels by using the plasma-catalyst hybrid converters with energy conservation was investigated. The energy saving schemes, namely, heat recycling and heat insulation were applied to enhance the hydrogen production. The results showed that the energy saving systems enabled the $\mathrm{O}_{2} / \mathrm{C}$ ratio to be decreased to reduce oxidation of hydrogen and carbon monoxide and thereby improving the concentration of hydrogen-rich gas. By heat recycling, the improvement in methane conversion efficiency in a lower fuel feeding rate was achieved; moreover, the hydrogen production increased significantly with the water-gas shifting reaction under the same operation parameters (Horng et al., 2008a, 2009). System analysis was conducted on a combined system for methane steam reforming comprising conventional hydrogen production and waste heat recovery from steelmaking. The results showed that the factors evaluated including the natural gas consumption, enthalpy flow, $\mathrm{CO}_{2}$ emission, cost, and exergy loss were improved for the waste heat recovery system. This supports the feasibility of hydrogen production from recovered waste heat. Moreover, the proposed system is expected to produce less $\mathrm{CO}_{2}$ emission due to less fuel consumption (Maruoka et al., 2010).

Combustion principles state that hydrogen has a high heating value and a high flame speed. If hydrogen can maintain the normal combustion efficiency in engine even at an extremely lean mixture, it would reduce fuel consumption and exhaust emissions. A small 
plasma fuel reformer was used to ionize the mixture of gasoline and air, and the reformate gas was directed into the internal combustion engine. The results clearly indicated that the low levels of NOx, CO and $\mathrm{HC}$ were obtained simultaneously (Cohn et al., 1996). The combustion characteristics of a hydrogen-gasoline mixture via mathematical models were explored. It was obtained that the best thermal efficiency was acquired at $8.0 \%$ of hydrogen by mass, and the specific energy consumption was significantly improved at $10 \%$ of hydrogen by mass. It also found that most of the pollutants emitted by engines were produced during the cold-start and warming-up processes. Using hydrogen-rich gas produced by fuel converters as an auxiliary fuel for the engine, or using it with catalysts in the exhaust pipes for rapidly heating the engine would greatly increase the energy using efficiency during the cold start and warming up; it would also reduce the emission of pollutants during the cold start of the engine, and reduce the emission of $\mathrm{NOx}, \mathrm{CO}$, and $\mathrm{HC}$ in the driving condition of the vehicle (AlJanabi \& Al-Baghdadi, 1999). The performance of hydrogen fueled carbureted and fuelinjected SI engine was compared. The results revealed that the fuel-injected engine gave better output power and had a lower risk of backfiring (Verhelst \& Sierens, 2001). Recycled exhaust and added methane and air for reforming with a honeycomb catalyst was studied on an HCCI (Homogenous Charge Compression Ignition) engine. By reusing the heat from the exhaust and adding external heat for partial oxidation reforming, steam reforming and water-gas shifting, the effect of temperature on reformate gas concentration and fuel conversion efficiency was investigated (Peucheret et al., 2005).

A set of small plasma fuel converter was designed for hydrogen production and applied on a 4-stroke motorcycle with a heat storing catalyst in the exhaust pipe to reduce exhaust emission. The results demonstrated that the exhaust emissions produced by the engine were extremely low in the cold-start process (Horng et al., 2006b). The driving performance and exhaust emission characteristics of a 125cc motorcycle equipped with an onboard plasma reformer for producing hydrogen-rich gas was investigated. The produced hydrogen-rich gas was induced into the internal combustion engine as supplementary fuel. It showed that the NOx emission was improved by $56.8 \%$ under a constant speed of $40 \mathrm{~km} / \mathrm{h}$. During transient driving condition, the improvement of $16 \%$ $41 \%$ in $\mathrm{NO} x$ concentration was achieved. The emissions of the motorcycle were also analysed on a chassis dynamometer tracing an ECE-40 driving pattern. The $\mathrm{NO}_{\mathrm{x}}$ emission was improved by $34 \%$, as was the $\mathrm{HC}$ emission by $4.08 \%$, although the $\mathrm{CO}$ emission was increased (Horng et al., 2008b). The performance of an engine by fuel injection with hydrogen was investigated, and the results showed that the knocking and backfiring were absent. The experiments included three operating parameters, namely, ignition timing, injection timing and equivalence ratio, all of which were optimised for the engine performance in terms of good thermal efficiency, good brake mean effective pressure, and low NOx emission (Mohammadi et al., 2007). The effect of hydrogen addition to a natural gas engine on engine performance and emission was studied. The results showed that adding hydrogen in lean burn condition could improve the thermal efficiency of engine with reducing the $\mathrm{CO}$ and $\mathrm{HC}$ emissions. However, an increase in NOx emission was obtained in the process due to the increase in the combustion temperature. They further showed that by modifying the ignition timing, the NOx emission could be reduced to that similar to the original fuelling system (Ma et al., 2007). 
An on-board plasmatron converter was used for hydrocarbon fuel reforming. The study proved that both high carbon and low carbon fuels could efficiently generate hydrogen-rich gas; and once it was directed into the engine, the thermal efficiency and NOx and CO emissions of the engine were evidently improved (Rabinovich et al., 1994). The investigation on the exhaust gas reforming of gasoline was carried out. The reformed fuel was fed to an engine as an additive to gasoline. The study on the effects of reformed fuel addition on engine performance at extreme lean burn conditions was performed. Results showed that low levels of NOx and HC emissions were achieved with the improved thermal efficiency and extended lean burn operation (Jamal et al., 1996). The hydrogen producing systems for powering vehicles were explored. The characteristics of different fuels on reducing exhaust emissions were compared and reported that the shape design of a reaction chamber could improve thermal management, reduce heat lost and optimize incubation time (Bromberg et al., 1999a). Hydrogen-rich gas produced from a plasmatron fuel converter with the exhaust gas recirculation (EGR) approach was directed into an internal combustion engine. The results showed that the NOx emission was evidently reduced with low level of HC emission under cold-start of the engine (Bromberg et al., 2001).

In summary, a fuel reformer for hydrogen production is to be a promising way in the future; and it would be one of the directions for application in internal combustion engines and fuel cells. This study attempts to develop a set of plasma fuel converter with waste heat recycling. The reformation of methane for hydrogen production is investigated, and the results are anticipated to serve as a reference for future research on the reformation of other fuels, including natural gas, or biogas. The application of this system is expected to improve the thermal efficiency and the exhaust emissions of engines. Additionally, the applications of fuel converters on fuel cells would be becoming popular. The stationary fuel converters could be applied for producing hydrogen on solid oxide fuel cells (SOFC). As for the portable fuel cells, if the purity of reformate gas can be achieved, the portable hydrogen generating device could be carried onboard vehicles directly to power vehicles with proton exchange membrane fuel cells (PEMFC).

\section{Experimental equipment and methodology}

\subsection{Experimental equipment}

This study focuses on the energy conservative plasma fuel converters with waste heat recycling; a photo and a schematic diagram of the experimental equipment of the system are shown in Fig. 1 and Fig. 2, respectively. The reaction chamber was comprised of three subsystems: the fuel and gas supply system, the arc generation system, and the reformate gas sampling and analyzing system. The fuel and gas supply system was comprised a fuel nozzle and a flow meter. For the arc generation system, a car ignition system was used with a signal generator and an induction coil to generate arc. Converting car ignition system into a small high voltage DC power supply is practical, as it enabled the system to be directly equipped on-board, and the use of the existing equipment reduced the required space and cost of power supply. The anode of the sparking electrode was constructed by removing the earth electrode of spark plug, while the cathode was the reaction chamber itself. The specifications of the arc generating system are shown in Table 1 (a). 
(a) Plasma power supply unit

\begin{tabular}{ccc}
\hline & Primary side & Secondary side \\
\hline Voltage (V) & 12 & 4000 \\
Current (A) & 3.0 & 0.004 \\
Power $(\mathrm{W})$ & 36 & 16 \\
Arc frequency $(\mathrm{Hz})$ & 200 & Variable \\
\hline
\end{tabular}

(b) Catalytic converter

\begin{tabular}{cc}
\hline $\mathrm{D} \times \mathrm{L}\left(\mathrm{mm}^{2}\right)$ & $\Phi 46.2 * 50.0$ \\
$\mathrm{Pt} / \mathrm{Rh}$ ratio & $5 / 1$ \\
Catalyst loading $\left(\mathrm{g} / \mathrm{ft}^{3}\right)$ & 50 \\
Cell density $\left(\right.$ Cell $\left./ \mathrm{in}^{2}\right)$ & 100 \\
\hline
\end{tabular}

Table 1. The specifications for the plasma converter and the catalyst

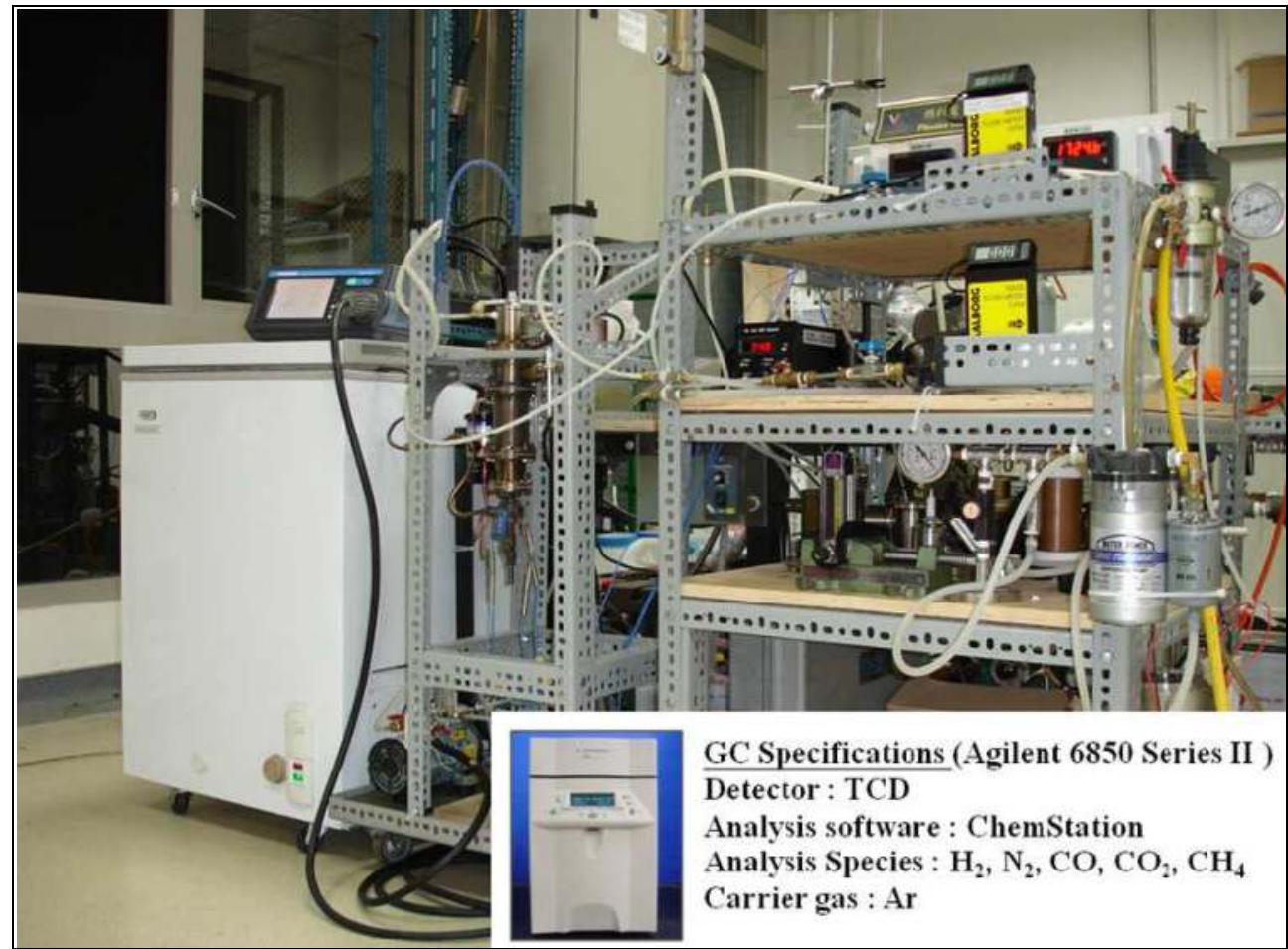

Fig. 1. Photo of the experimental equipment 


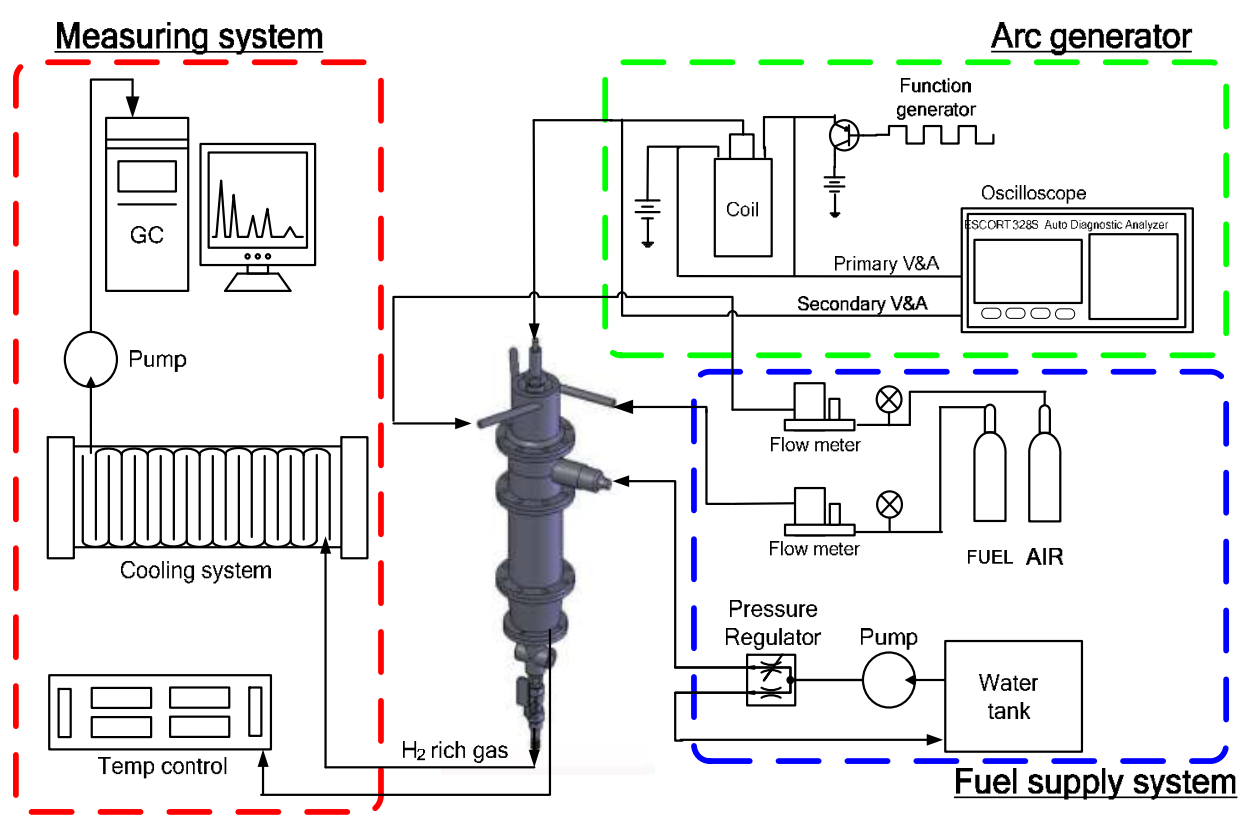

Fig. 2. A schematic diagram of the experimental set-up

The reformate gas sampling system of this experiment was designed to collect products from reforming reactions. A portion of the products was distributed to vehicle exhaust emission analyzer (Horiba MEXA-554JA) via pump to monitor the concentrations of the gas product. Another portion of the product was collected in the gas bags and directed into gas chromatography (Agilent 6850GC) for analysis. The reaction chamber was made of stainless steel, and could be further classified into the plasma reaction zone, the middle chamber, the catalyst section, the gas collecting chamber, and the fuel nozzle, as shown in Fig. 3. The internal surface of the reaction chamber was the ground electrode and the arc could be stretched freely with the intake flow. That is, the arcing system and the ground electrode were designed so as to enhance the uniform distribution of the discharge energy in the plasma reaction region. The main function of the catalyst section was to enhance the reforming reactions. The gas collection chamber was designed to thoroughly mix the reformate gas for sampling.

The commercialized catalysts were used for reforming, and the specifications of which are shown in Table 1 (b). This commercialized catalyst was chosen for its low cost, availability, small pressure drops, and great mechanical strength; in addition, the catalyst has a metal substrate, and therefore has an advantage of rapid cold-start.

The energy conservation measures of this study could be classified into waste heat recycling and heat insulation. For the heat recycling method, a stainless steel cover was added to form an air jacket on the catalyst outer wall, to direct the hot reformate gas back into the air jacket for heat recovery. For the heat insulation method, the outer surface of the reaction chamber was covered with glass fiber. The reaction temperature of the catalysts at the front, middle, and rear sections were measured via three K-type thermocouples. The average temperatures 


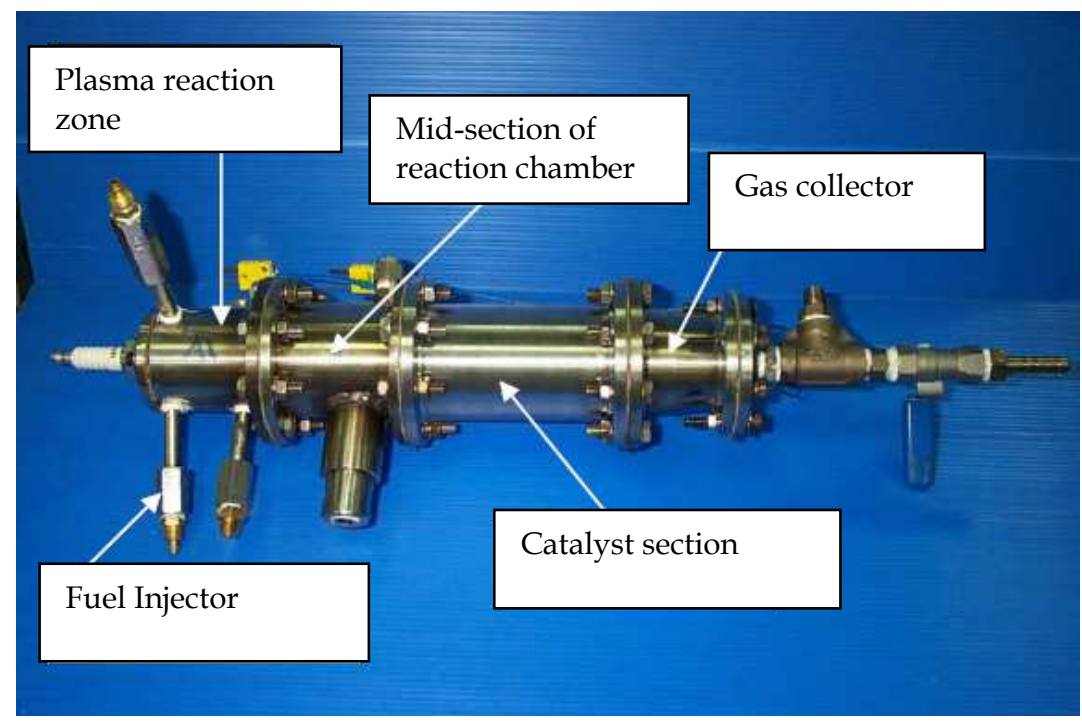

Fig. 3. The configuration of the reactor

at the three points were used to define the actual temperature of the reformate gas. This temperature was also used to correspond with the theoretical calculation to verify the trend of the experimental results.

\subsection{Methodology}

In this study, the fuel was reformed by coupling the arc energy from a spark discharge with the catalyst converter for partial oxidation reforming. The arc was the external energy source of the system to cause the formation of the plasma; and the arc was stretched by the kinetic energy induced by the tangential intake air flow which allowed for a more even discharge distribution. In addition, the production of hydrogen-rich gas was improved due to the use of catalysts. The product was collected in gas bags for analysis via gas chromatography.

Currently, the industries have several approaches for producing hydrogen; these approaches can be classified into three main categories, based on the energy sources: (1) Hydrogen production via hydrocarbon fuels; (2) hydrogen production via non-hydrocarbon fuels; and (3) hydrogen production via a combination of hydrocarbon and non-hydrocarbon fuels. Other classification for hydrogen production includes steam reforming (SR), partial oxidation reforming (POX), autothermal reforming (ATR), catalytic decomposition, and coal gasification. The reforming approaches and mechanisms for hydrogen production are shown in Fig. 4. This study generated hydrogen by the reformation of hydrocarbon fuels by POX and ATR.

Fig. 5 shows the variation of the reformate gas yields produced by methane under various $\mathrm{O}_{2} / \mathrm{CH}_{4}$ ratios at different reforming temperatures by theoretical calculation. It showed that the temperature of the reformate gas was crucial for the overall yield; higher reaction 


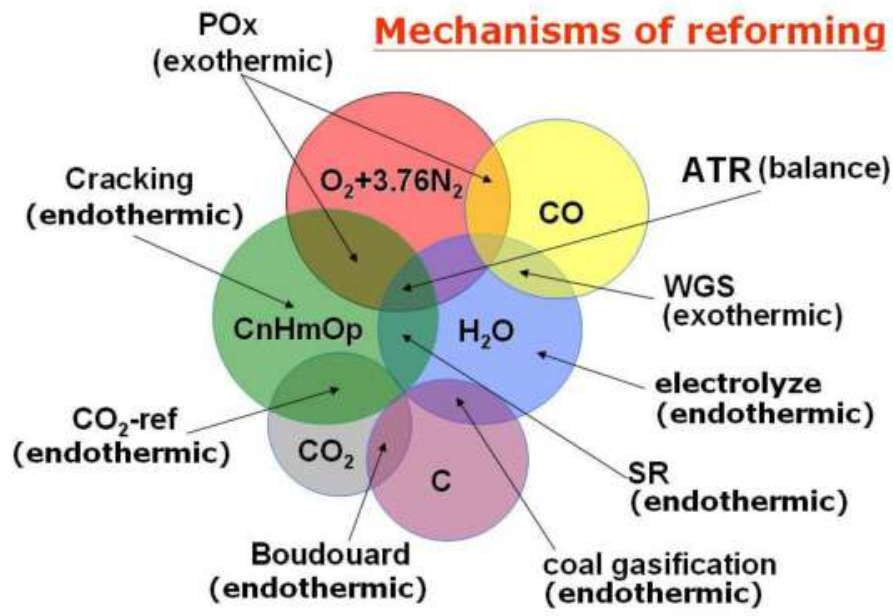

Fig. 4. A relationship chart of reforming mechanisms

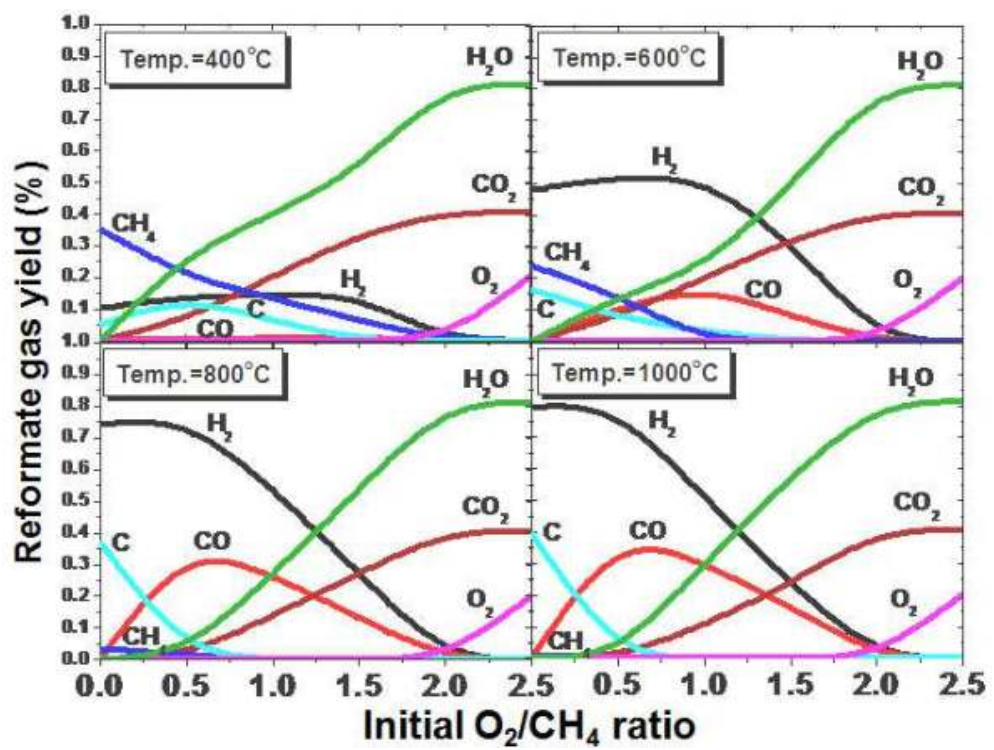

Fig. 5 . The variation of the reformate gas yields produced by methane under various $\mathrm{O}_{2} / \mathrm{CH}_{4}$ ratios at different reforming temperatures

temperatures and lower $\mathrm{O}_{2} / \mathrm{CH}_{4}$ ratios gave better $\mathrm{H}_{2}$ and $\mathrm{CO}$ yields. However, the appeal of this system was its portability, and thus external energy supply was not an option. Therefore, heat released during the oxidation reforming process was used to provide the high temperature required for the reactions. This approach reduced the need for external energy, and was also advantageous in minimizing the size of the converter. 
Fig. 6 shows the enthalpy of reaction under different $\mathrm{O}_{2} / \mathrm{C}$ ratios in methane reforming processes. The spots in the figure represent different reaction processes, and the processes are displayed sequentially as: the cracking process, the partial oxidation process, and the complete combustion. It could be observed that lower $\mathrm{O}_{2} / \mathrm{C}$ ratios were involved in endothermic processes, as lower $\mathrm{O}_{2} / \mathrm{C}$ ratios could not provide the required energy for the reformation processes. Therefore, methane of a higher $\mathrm{O}_{2} / \mathrm{C}$ ratio was used in this study for reforming reactions. However, $\mathrm{O}_{2} / \mathrm{C}$ could not be too high, or $\mathrm{H}_{2}$ and $\mathrm{CO}$ would be oxidized into $\mathrm{H}_{2} \mathrm{O}$ and $\mathrm{CO}_{2}$. This study contained the $\mathrm{O}_{2} / \mathrm{C}$ ratio between $\mathrm{B}$ and $\mathrm{C}$, as shown in Fig. 6; methane reaction with $\mathrm{O}_{2} / \mathrm{C}$ ratios within this range provided the required energy for reforming, and simultaneously prevented a reduction in catalyst activity due to the formation of carbon deposition in fuel rich when the $\mathrm{O}_{2} / \mathrm{C}$ ratio was too low. Many possible reaction processes may happen for this study; the reactions listed in Table 2 are the possible routes, such as oxidation, shifting, and methanation, which could occur in this study.

\begin{tabular}{ccc}
\hline Reaction & Equation & $\begin{array}{c}\Delta \mathrm{H}_{\mathrm{STP}} \\
(\mathrm{kJ} / \mathrm{mol})\end{array}$ \\
\hline Partial oxidation & $\mathrm{CH}_{4}+0.5 \mathrm{O}_{2} \rightarrow \mathrm{CO}+2 \mathrm{H}_{2}$ & -35.6 \\
Water gas shifting & $\mathrm{CO}+\mathrm{H}_{2} \mathrm{O} \rightarrow \mathrm{CO}_{2}+\mathrm{H}_{2}$ & -41.2 \\
Complete oxidation & $\mathrm{CH}_{4}+2 \mathrm{O}_{2} \rightarrow \mathrm{CO}_{2}+2 \mathrm{H}_{2} \mathrm{O}$ & -802.2 \\
$\mathrm{H}_{2}$ oxidation & $\mathrm{H}_{2}+0.5 \mathrm{O}_{2} \rightarrow \mathrm{H}_{2} \mathrm{O}$ & -241.8 \\
CO oxidation & $\mathrm{CO}+0.5 \mathrm{O}_{2} \rightarrow \mathrm{CO}_{2}$ & -283.0 \\
$\mathrm{CO}$ methanation & $\mathrm{CO}+3 \mathrm{H}_{2} \rightarrow \mathrm{CH}_{4}+\mathrm{H}_{2} \mathrm{O}$ & -206.2 \\
$\mathrm{CO}_{2}$ methanation & $\mathrm{CO}_{2}+4 \mathrm{H}_{2} \rightarrow \mathrm{CH}_{4}+2 \mathrm{H}_{2} \mathrm{O}$ & -165.0 \\
\hline
\end{tabular}

Table 2 . The reaction in the reforming processes and the corresponding enthalpy of reaction

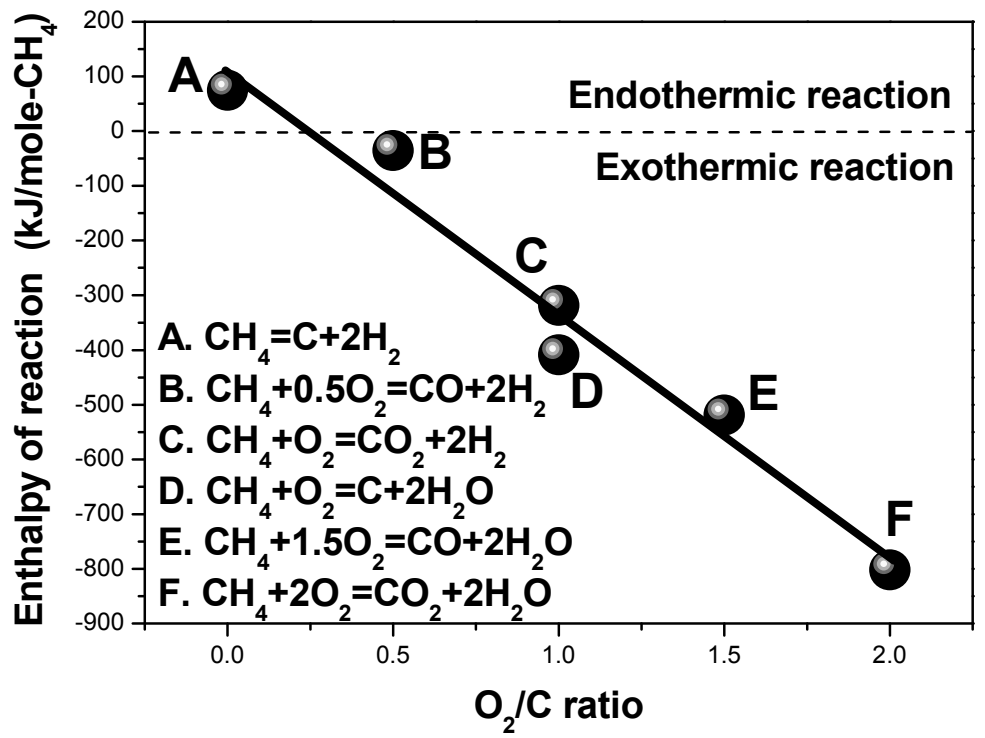

Fig. 6. A comparison of the enthalpy of reaction under different $\mathrm{O}_{2} / \mathrm{C}$ ratios in methane reforming processes 


\subsection{Experimental parameters and the related calculations}

In this study, the methane flow rate was in the range of 1 to $10 \mathrm{~L} / \mathrm{min}$, the $\mathrm{O}_{2} / \mathrm{C}$ (Oxygen/Carbon) ratio was between 0.5 and 1.0, S/C $\left(\mathrm{H}_{2} \mathrm{O} / \mathrm{Carbon}\right)$ ratio was between 0 and 2, and the arc frequency was $200 \mathrm{~Hz}$. Methane and air were supplied from tanks and were directed into the plasma reaction zone through the fuel nozzle via a tangential induction. The frequency of the arc was controlled by the signal generator, and was monitored on an oscilloscope. This study measured the voltage and current of the primary side (the low-voltage side), and monitored the arc frequency with an oscilloscope and a clamp tester. The voltage and current of the secondary side (high-voltage side) was measured with the oscilloscope and the clamp tester, in coordination with an automotive diagnostic analyzer.

Partial oxidation and autothermal reforming reactions were performed in this study. With an appropriate amount of oxygen, the heat released from the fuel oxidization dissociated carbon $(\mathrm{C})$ and hydrogen $(\mathrm{H})$ atoms from the fuel with water addition, and reformed the atoms into hydrogen gas $\left(\mathrm{H}_{2}\right)$ and carbon monoxide $(\mathrm{CO})$. The equations (1) - (4) below represent the theoretical and actual reactions.

1. Theoretical reactions

Partial oxidation reforming

$$
\mathrm{CH}_{4}+\mathrm{z}_{0}\left(\mathrm{O}_{2}+3.76 \mathrm{~N}_{2}\right) \rightarrow 2 \mathrm{z}_{0} \mathrm{CO}+2 \mathrm{H}_{2}+\left(1-2 \mathrm{z}_{0}\right) \mathrm{C}+3.76 \mathrm{z}_{0} \mathrm{~N}_{2}
$$

Autothermal reforming

$$
\mathrm{CH}_{4}+\mathrm{z}_{0}\left(\mathrm{O}_{2}+3.76 \mathrm{~N}_{2}\right)+\left(2-2 \mathrm{z}_{0}\right) \mathrm{H}_{2} \mathrm{O} \rightarrow \mathrm{CO}_{2}+\left(4-2 \mathrm{z}_{0}\right) \mathrm{H}_{2}+3.76 \mathrm{z}_{0} \mathrm{~N}_{2}
$$

2. Actual reactions

Partial oxidation reforming

$$
\mathrm{CH}_{4}+\mathrm{z}\left(\mathrm{O}_{2}+3.76 \mathrm{~N}_{2}\right) \rightarrow \mathrm{x}\left(\mathrm{aCO}+\mathrm{bCO}_{2}+\mathrm{dH}_{2}+\mathrm{eO}_{2}+\mathrm{fCH}_{4}+\mathrm{gN}_{2}\right)+\mathrm{hH}_{2} \mathrm{O}+\mathrm{jC}
$$

Autothermal reforming

$$
\mathrm{CH}_{4}+\mathrm{z}\left(\mathrm{O}_{2}+3.76 \mathrm{~N}_{2}\right)+\mathrm{yH} \mathrm{H}_{2} \mathrm{O} \rightarrow \mathrm{x}\left(\mathrm{aCO}+\mathrm{bCO}_{2}+\mathrm{dH}_{2}+\mathrm{eO}_{2}+\mathrm{fCH}_{4}+\mathrm{gN}_{2}\right)+\mathrm{hH}_{2} \mathrm{O}+\mathrm{jC}
$$

$z_{0}$ is the equilibrium constant in the theoretical reaction; $z, a, b, d, e, f, g, h, j$ and $y$ are the equilibrium constants in the actual reaction, and $x$ is the proportionality constant, respectively. Several expressions are used to describe the ratio of fuel and air in chemical equilibrium, and can be mainly classified as air-fuel mass ratio, and oxygen-carbon molar ratio. This study expressed the reforming reaction processes using the oxygen-carbon molar ratio. The equation for the oxygen-carbon $\left(\mathrm{O}_{2} / \mathrm{C}\right)$ ratio related to volumetric flow rate is shown in equation (5).

$$
\frac{\mathrm{O}_{2}}{\mathrm{C}}=\frac{\dot{n}_{\mathrm{O}_{2}}}{\dot{n}_{\mathrm{CH}_{4}}}=\frac{\frac{\dot{m}_{\mathrm{O}_{2}}}{M_{\mathrm{O}_{2}}}}{\frac{\dot{m}_{\mathrm{CH}_{4}}}{M_{\mathrm{CH}_{4}}}}=\frac{\rho_{\mathrm{O}_{2}} \times Q_{\mathrm{O}_{2}}}{\rho_{\mathrm{CH}_{4}} \times Q_{\mathrm{CH}_{4}}} \times \frac{M_{\mathrm{CH}_{4}}}{M_{\mathrm{O}_{2}}}=\frac{0.21 \times Q_{\text {air }}}{Q_{\mathrm{CH}_{4}}}
$$


Where $\dot{n}, \dot{m}$ and $Q$ represent the molar, mass and volumetric flow rates of the species, respectively; $M$ and $\rho$ represent the molecular weight and density, respectively.

Generally, chemical equilibrium is described by two methods, the equilibrium constant and the minimum of Gibbs free energy. This study described the state of the reforming process by temperature and pressure. Gibbs free energy can easily achieve minimization; in addition, temperature and pressure are both the original variables of the Gibbs function; therefore, this study took the Gibbs free energy minimization for calculation. The calculation and analysis were performed using the commercialized HSC Chemistry software ( ${ }^{\circ}$ ChemSW Software, Inc., 2002). HSC software was designed to analyze many different types of chemical reactions and to perform equilibrium calculations. This study used the HSC system to find the equilibrium components, and the thermodynamic properties. The predicted results were then used as a reference to set the parameters and to validate the experimental results.

\section{Results and discussion}

\subsection{The effect of $\mathrm{O}_{2} / \mathrm{C}$ ratio}

Fig. 7 shows the effect of $\mathrm{O}_{2} / \mathrm{C}$ ratio on $\mathrm{H}_{2}+\mathrm{CO}$ concentration at various fuel flow rates. $\mathrm{H}_{2}+\mathrm{CO}$ is generally known as syngas, it can be directed into an engine as a fuel, or be processed via a water gas shifting reaction or a gas separation method for fuel cell applications. The overall trend shows that the higher the input fuel flow rate, the greater the $\mathrm{H}_{2}+\mathrm{CO}$ output concentration; and within the tested parameter range, the output concentration gradually converges as the flow rate increases. Particularly, at a low flow rate and a low $\mathrm{O}_{2} / \mathrm{C}$ ratio, a great amount of the fuel cannot be converted due to a lower heat

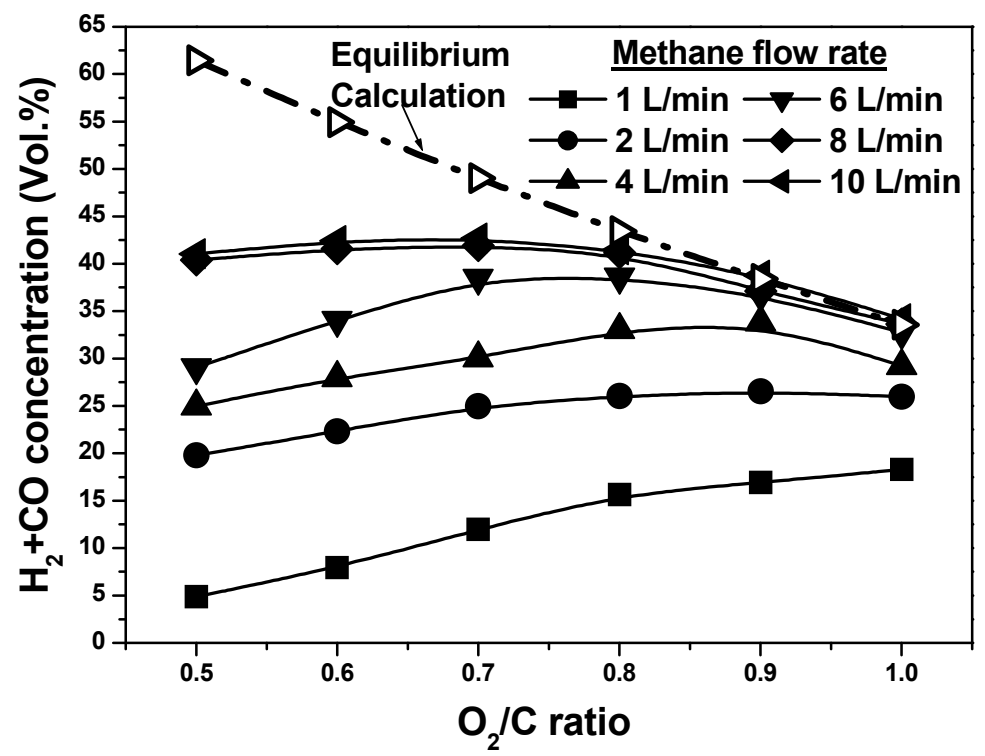

Fig. 7. The influence of $\mathrm{O}_{2} / \mathrm{C}$ ratios on the output concentration of $\mathrm{H}_{2}+\mathrm{CO}$ at different methane flow rates 
release, resulting in a lower $\mathrm{H}_{2}+\mathrm{CO}$ concentration. Therefore, higher $\mathrm{O}_{2} / \mathrm{C}$ ratios are required to generate greater $\mathrm{H}_{2}+\mathrm{CO}$ output concentrations at low input flow rates. In contrast, the oxidization effect is stronger at greater flow rates and higher $\mathrm{O}_{2} / \mathrm{C}$ ratios; consequently, $\mathrm{H}_{2}$ and $\mathrm{CO}$ would combine with excess $\mathrm{O}_{2}$ to form $\mathrm{CO}_{2}$ and $\mathrm{H}_{2} \mathrm{O}$; the overall $\mathrm{H}_{2}+\mathrm{CO}$ output concentration also decreases due to the large quantity of dilute gas $\left(\mathrm{N}_{2}\right)$. Further in this figure, it is observed that the differences between the theoretical calculation and the experimental results in $\mathrm{H}_{2}+\mathrm{CO}$ concentrations are obvious at low $\mathrm{O}_{2} / \mathrm{C}$ ratios. This is mainly because the low heat release of oxidation at lower $\mathrm{O}_{2} / \mathrm{C}$ ratios leads to a lower conversion efficiency. Therefore, when the $\mathrm{O}_{2} / \mathrm{C}$ ratio is low, waste heat recycling could be simultaneously used to improve the fuel conversion efficiency, and thus increase the overall reforming efficiency.

The effect of $\mathrm{O}_{2} / \mathrm{C}$ ratio on the enthalpy of reaction and energy loss will be discussed in the following section. The change of enthalpy of reaction $(\Delta H)$ is denoted in equation (6).

$$
\Delta H=\sum_{\text {Product }} n_{e}\left(\overline{h_{f}^{0}}+\overline{\Delta h}\right)_{e}-\sum_{\text {Reactant }} n_{i}\left(\overline{h_{f}^{0}}+\overline{\Delta h}\right)_{i}
$$

Where $n, \overline{h_{f}^{0}}$ and $\overline{\Delta h}$ represent the number of kilogram-moles, enthalpy of formation and enthalpy change of species $e$ and $i$ for the products and reactants, respectively.

Fig. 8 shows the effect of $\mathrm{O}_{2} / \mathrm{C}$ ratio on the enthalpy of reaction and the energy loss at different methane flow rates in the reforming process. Greater energy loss implies greater heat release in the reforming process. By comparing different $\mathrm{O}_{2} / \mathrm{C}$ ratios at the same fuel flow rate, it is found that more oxygen reacts with the fuel at higher $\mathrm{O}_{2} / \mathrm{C}$ ratios, therefore more heat is released. Consequently, excessive oxygen has a tendency to oxidize $\mathrm{H}_{2}$ and $\mathrm{CO}$ to become $\mathrm{H}_{2} \mathrm{O}$ and $\mathrm{CO}_{2}$, respectively, resulting in a greater loss of energy in the reaction

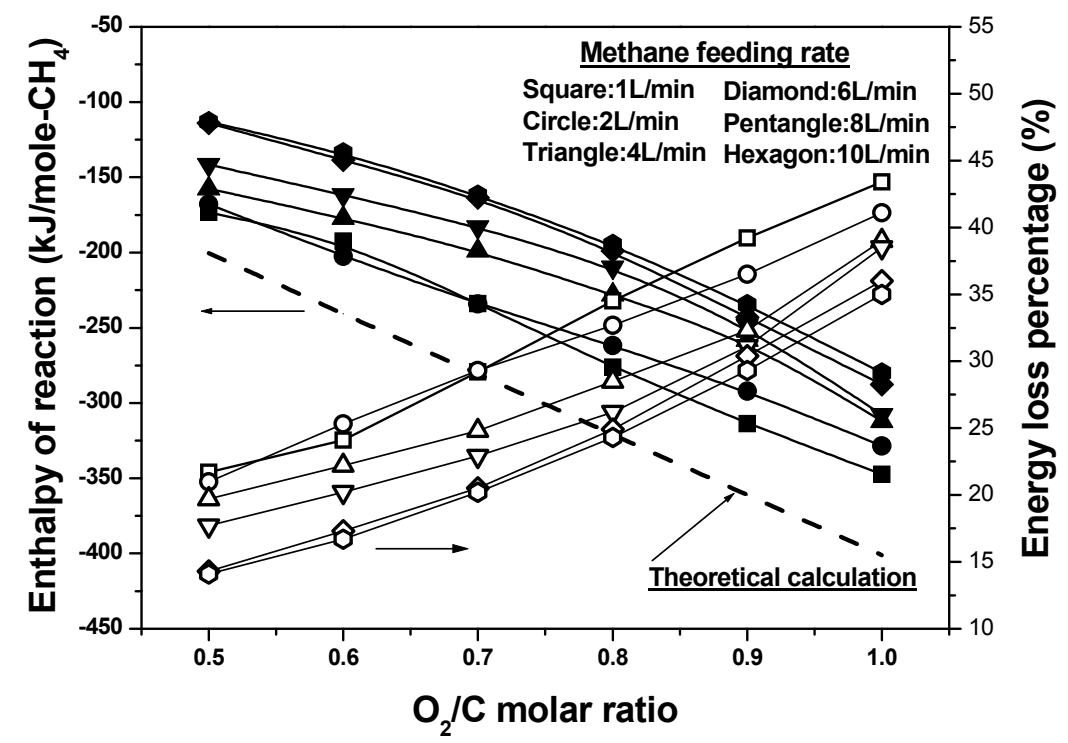

Fig. 8. The relationship between various $\mathrm{O}_{2} / \mathrm{C}$ ratios and the enthalpy of reaction and energy loss percentage at different methane flow rates 
process. In contrast, by comparing different fuel flow rates at the same $\mathrm{O}_{2} / \mathrm{C}$ ratio, it is found that increasing the fuel flow rate would lower the enthalpy of reaction per molar fuel. This is because the fuel oxidation releases more heat and the reaction temperature is relatively high; therefore, in this condition, the system does not rely on higher $\mathrm{O}_{2} / \mathrm{C}$ ratios to promote the conversion of fuel. As a result, the overall energy loss percentage decreases as the fuel flow rate increases.

\subsection{The effect of fuel supply rate}

Conversion efficiencies are crucial indicators of reforming processes and can be used to indicate the reformation efficiency. Higher conversion efficiency implies that more fuel participates in the reactions, therefore more reformate products are produced. As shown in Fig. 9, the methane flow rates of this study are $2,4,6,8$, and $10 \mathrm{~L} / \mathrm{min}$, and the $\mathrm{O}_{2} / \mathrm{C}$ ratio is between 0.5 and 1.0. High fuel conversion efficiency is found at relatively high $\mathrm{O}_{2} / \mathrm{C}$ ratios and high methane flow rates. This is because at the same $\mathrm{O}_{2} / \mathrm{C}$ ratio, an increase in the flow rate of fuel would increase the heat release of oxidation; therefore the required energy for reaction is effectively obtained. It is also found that as the $\mathrm{O}_{2} / \mathrm{C}$ ratio increases, the increase in conversion efficiency gradually slows down because it nearly reaches the maximum space velocity of the reforming system.

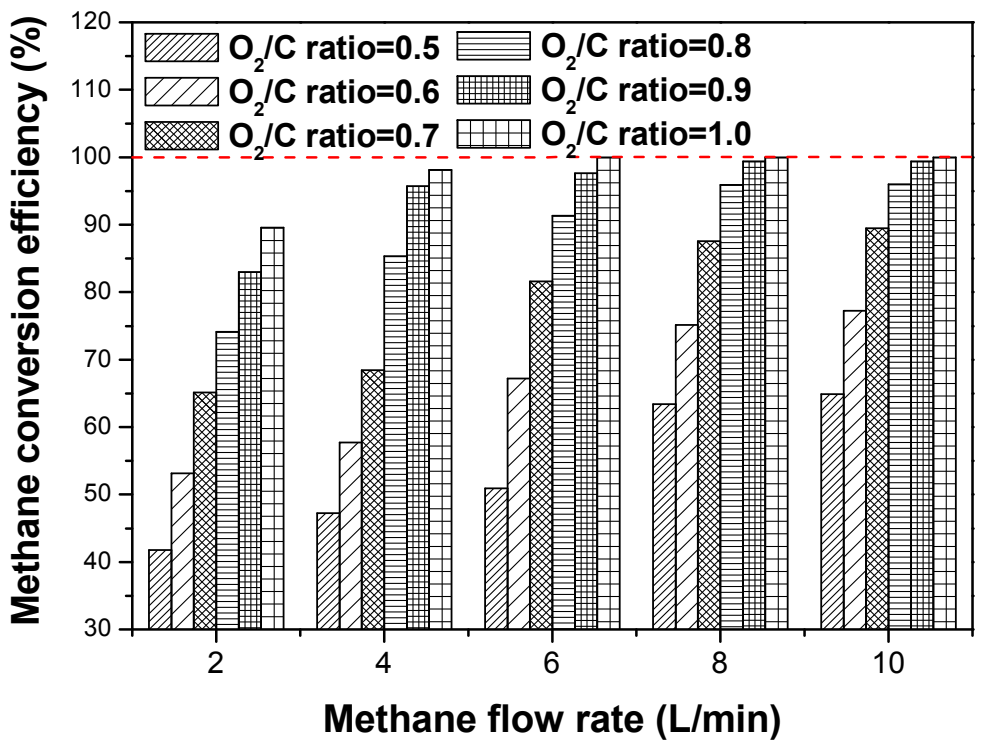

Fig. 9. The effect of methane flow rate on methane conversion efficiency at different $\mathrm{O}_{2} / \mathrm{C}$ ratios

\subsection{The effect of the reformate gas temperature}

The following section discusses the effect of reformate gas temperature on the selectivity of $\mathrm{H}_{2}$ and $\mathrm{CO}$. The definition of selectivity $(S)$ is shown in equations (7) and (8), and can be classified as carbon-based (C-base) and hydrogen (H-base) selectivity. 


$$
\begin{aligned}
& S_{\text {C-base }}=\frac{x}{n}\left(\frac{\text { moles of } \mathrm{C} x H y \text { formed }}{\text { moles of CnHm consumed }}\right) \times 100 \% \\
& S_{H-\text { base }}=\frac{y}{m}\left(\frac{\text { moles of } C x H y \text { formed }}{\text { moles of } \mathrm{C} n \mathrm{H} \text { m consumed }}\right) \times 100 \%
\end{aligned}
$$

The selectivity is to demonstrate the form of the reformate gas existing after the reforming reactions. Briefly, hydrocarbon fuel reformation produces hydrogen-based and carbonbased products. The selectivity of hydrogen-based product may have the form of hydrogen $\left(\mathrm{H}_{2}\right)$, water $\left(\mathrm{H}_{2} \mathrm{O}\right)$, or other hydrocarbons. Carbon-based products may exist as carbon monoxide $(\mathrm{CO})$, carbon dioxide $\left(\mathrm{CO}_{2}\right)$, and other hydrocarbons. Fig. 10 shows that as the temperature increases, $\mathrm{H}_{2}$ selectivity shows a quadratic increase, while $\mathrm{CO}$ selectivity has a logarithmic increase. Both $\mathrm{H}_{2}$ and $\mathrm{CO}$ have the greatest selectivity when the temperature is between $600{ }^{\circ} \mathrm{C}$ and $700{ }^{\circ} \mathrm{C}$. In Fig. 11, the yields of $\mathrm{H}_{2}$ and $\mathrm{CO}$ are found to increase as the reformate gas temperature rises; the yield reaches the maximum value approximately between 750 and $800{ }^{\circ} \mathrm{C}$, and is $77 \%$ for $\mathrm{H}_{2}$ and $73 \%$ for $\mathrm{CO}$. As performing the calculation by using the best parameters, the experimental results are found to be close to the theoretical values; except that once the reformate gas temperature exceeds $800{ }^{\circ} \mathrm{C}$, the experimental values diverge from the theoretical ones. Around this temperature, the inconsistency between the experimental results and the theoretical calculations is thought to result from the combustion of a portion of the methane at such a high temperature, and $\mathrm{H}_{2}$ and $\mathrm{CO}$ were oxidized to form the $\mathrm{CO}_{2}$ and $\mathrm{H}_{2} \mathrm{O}$.

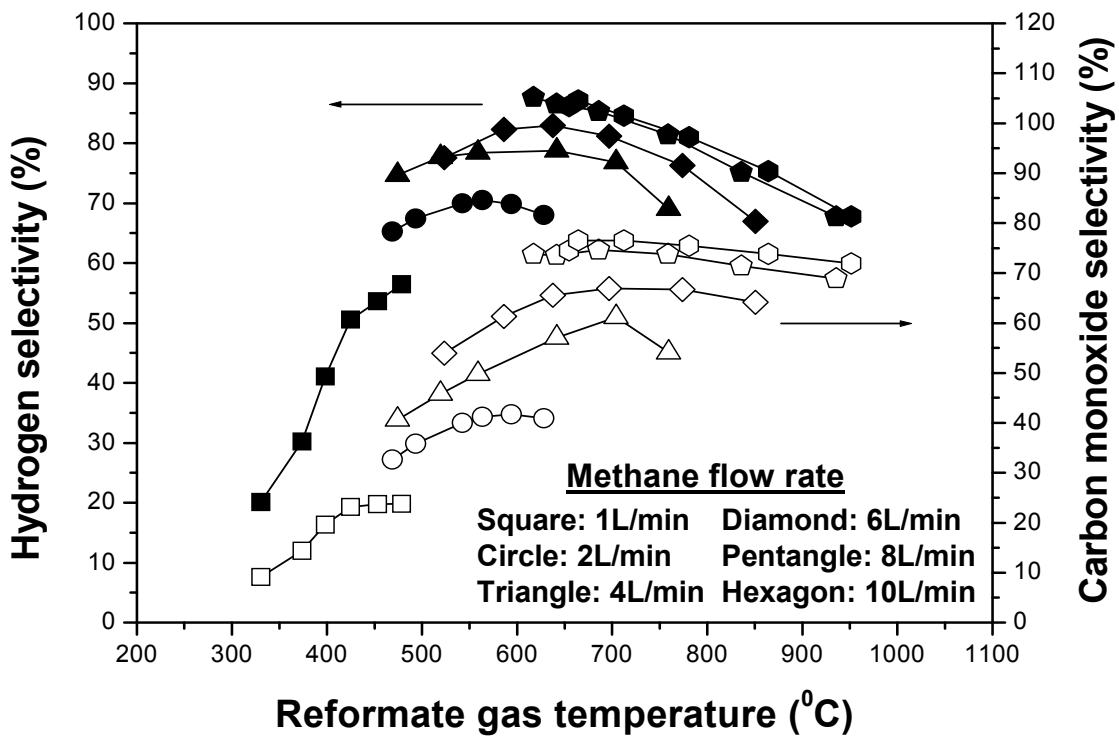

Fig. 10. The relationship between the reformate gas temperature and the selectivity of $\mathrm{H}_{2}$ and $\mathrm{CO}$ at different methane flow rates 


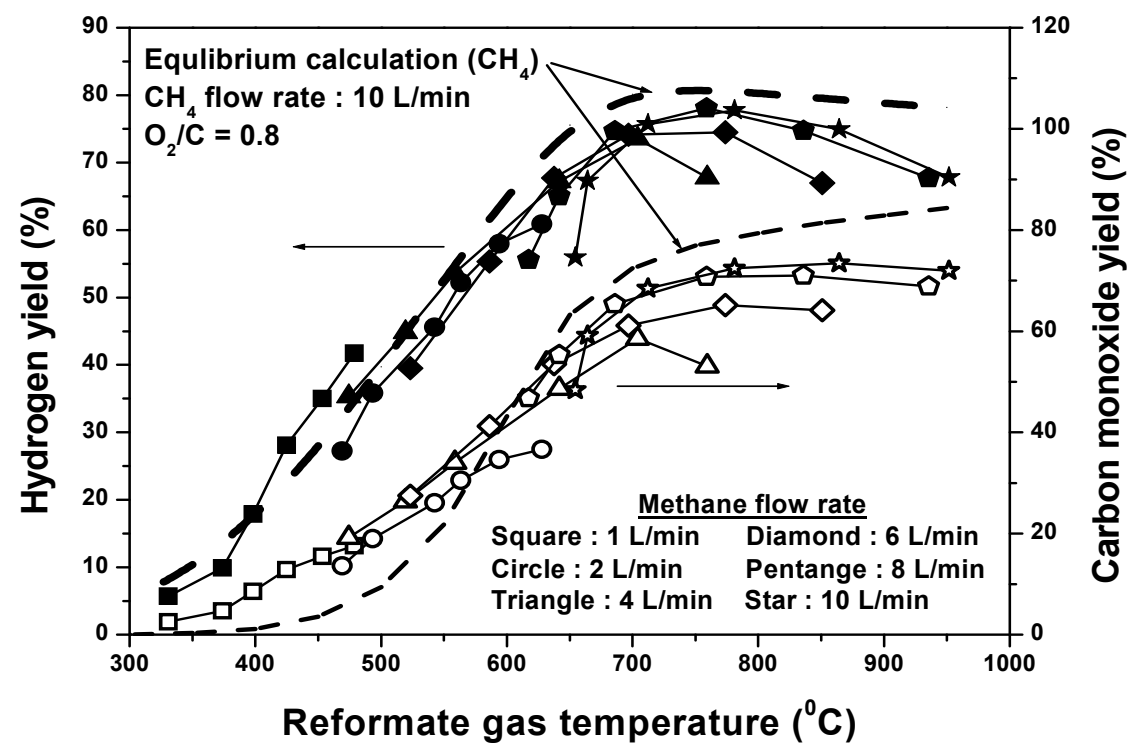

Fig. 11. The relationship between the reformate gas temperature and the yield of $\mathrm{H}_{2}$ and $\mathrm{CO}$ at different methane flow rates

\subsection{The effect of space velocity}

Generally, space velocity is determined by the input mixture, the operating temperature, and the size of the catalyst. Space velocity mainly refers to the volumetric flow rate of input mixture per unit volume of catalyst bed, but it is also an indicator for the reforming capacity. Fig. 12 shows the effect of space velocity on thermal efficiency at different methane flow rates and $\mathrm{O}_{2} / \mathrm{C}$ ratios. The definition for thermal efficiency $\left(\eta_{t h}\right)$ is as shown in equation (9).

$$
\eta_{\text {th }}=\frac{\dot{m}_{\mathrm{H}_{2}} L H V_{\mathrm{H}_{2}}+\dot{m}_{\mathrm{CO}} L H V_{\mathrm{CO}}}{\dot{m}_{\text {fuel }} L H V_{\text {fuel }}} \times 100 \%
$$

Where $\dot{m}$ and $L H V$ represent the mass flow rate and lower heating value of the species, respectively.

It is apparent from Fig. 12 that as space velocity increases, thermal efficiency initially increases abruptly, and the rate of increase slows down soon after; the trend indicates that the parameters used in the system did not exceed the amount that the reforming system could treat. At best operating parameters (methane flow rate of $10 \mathrm{~L} / \mathrm{min}$ and an $\mathrm{O}_{2} / \mathrm{C}$ ratio of 0.8 ), the greatest thermal efficiency of $72.25 \%$ is obtained and the corresponding space velocity is approximately $35,000 \mathrm{~h}^{-1}$. The best operating parameters were used as the input for calculation by using a commercialized HSC program, and the calculated values were compared with the experimented results obtained from the best parameter setting of the reforming system. It can be observed from Fig. 13 that the difference in the reformate gas concentration between the theoretical and the experimental results is within $1 \%$. 


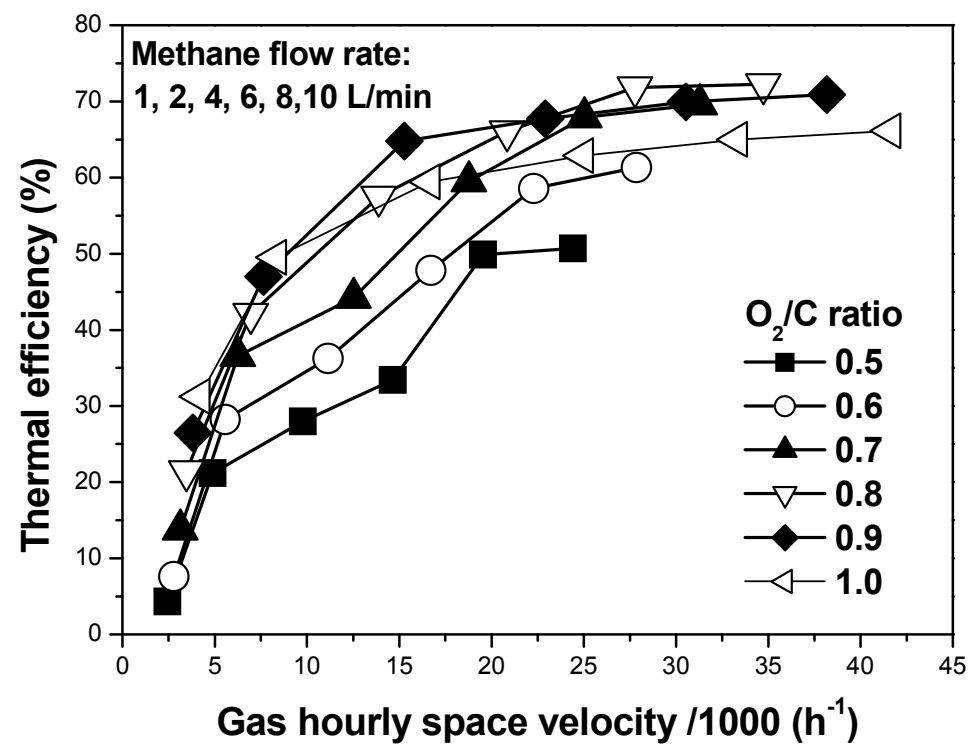

Fig. 12. The effect of space velocity on thermal efficiency at different methane flow rates and $\mathrm{O}_{2} / \mathrm{C}$ ratios

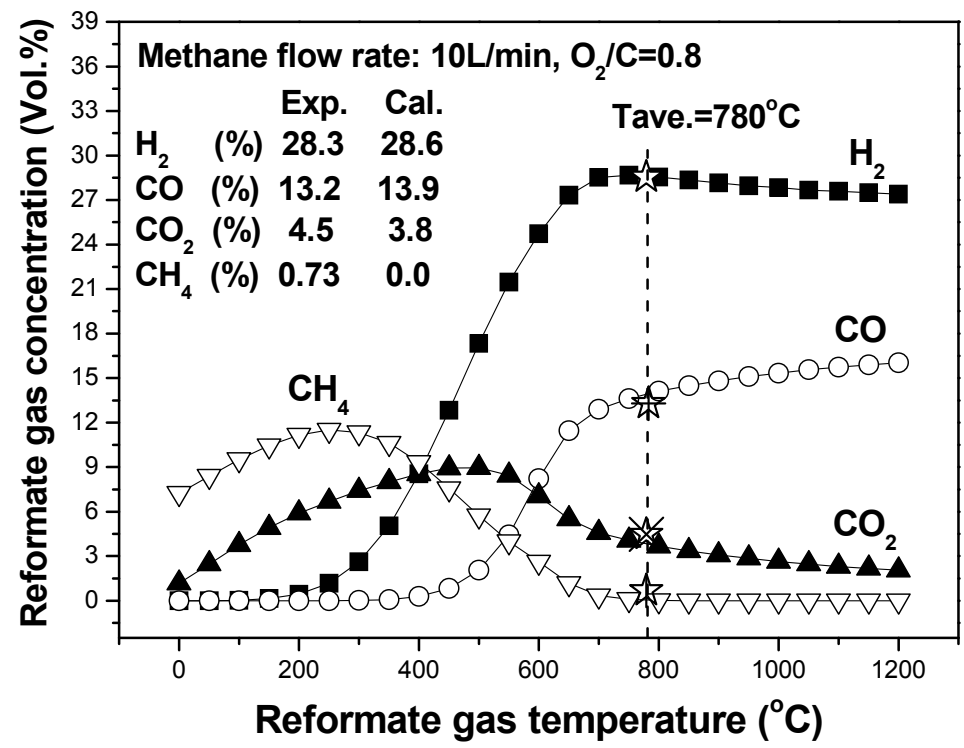

Fig. 13. Comparison of the theoretical calculations and the experimental results at the best parameter settings 
The reforming performance for all the parameters at different equivalent power of input fuel is compared, as shown in Fig. 14. The input power of fuel directed into the reaction chamber is shown on the horizontal axis, and the output power derived from the output flow rate of $\mathrm{H}_{2}$ and $\mathrm{CO}$ is shown on the vertical axis. The result of this study shows that when methane is used for reforming, the output power increases linearly with the input power. The linear regression result could also serve as a convenient reference for future parameter settings for reforming.

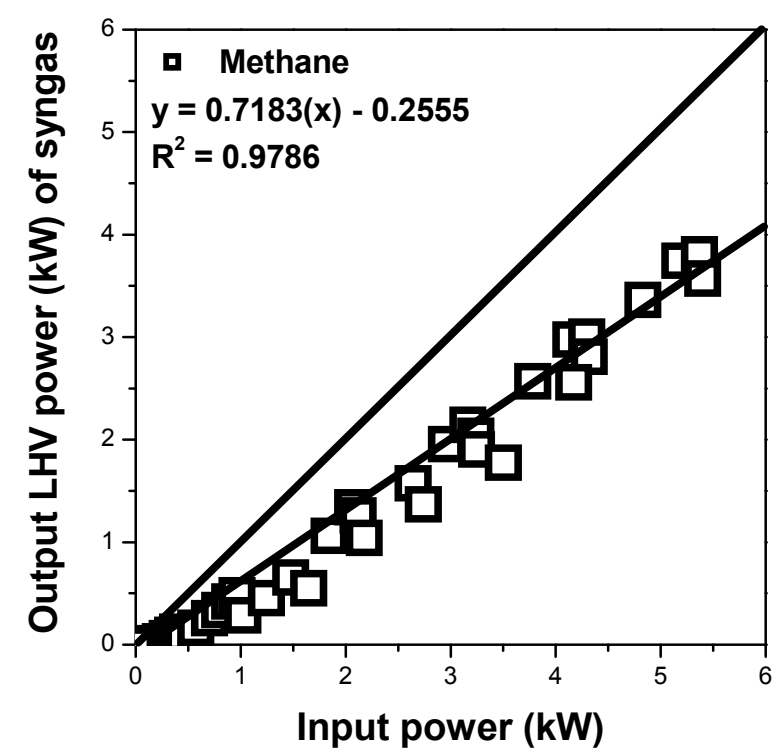

Fig. 14. Comparison of reforming performance at different input power

\subsection{The effect of the operating conditions on the reformation efficiency}

The following section discusses the variations in reformation efficiency under different operating conditions. The increase in hydrogen output and the reforming thermal efficiency were compared under the different water vapor addition, and under the use of different energy conservation approaches.

Table 3 shows the comparison of performance of the plasma fuel converter under different operating conditions, where symbol A represents the original system, i.e. the partial oxidation reforming, and $\mathrm{B}$ represents the autothermal reforming reaction with water vapor added. $C$ and D use different energy conservation approaches; $C$ represents the heat recycling approach, and $\mathrm{D}$ represents the heat insulation. The fuel flow rate is set at 10 $\mathrm{L} / \mathrm{min}$ and the $\mathrm{O}_{2} / \mathrm{C}$ ratio at 0.8 . The summary of results shown in Table 3 indicates that the best operating condition of this study is the combination of $A+D$, which has a maximum thermal efficiency of $77.77 \%$; the combination can be applied to internal combustion engines to promote energy utilization efficiency in the future. However, from the perspective of hydrogen production, the combination of $\mathrm{A}+\mathrm{B}+\mathrm{D}$ with an appropriate amount of water vapor for reaction would increase the hydrogen yield by approximately $5 \%$; it would also 


\begin{tabular}{ccccccc}
\hline & $\begin{array}{c}\text { S/C } \\
\text { ratio }\end{array}$ & $\begin{array}{c}\text { Fuel Conv. } \\
(\%)\end{array}$ & $\begin{array}{c}\mathrm{H}_{2} \text { yield } \\
(\%)\end{array}$ & $\begin{array}{c}\text { CO yield } \\
(\%)\end{array}$ & $\begin{array}{c}\text { Energy loss } \\
(\%)\end{array}$ & $\begin{array}{c}\eta_{\text {th }} \\
(\%)\end{array}$ \\
\hline $\mathrm{A}$ & n/a & 95.99 & 77.75 & 72.44 & 24.34 & 72.25 \\
$\mathrm{~A}+\mathrm{B}$ & 0.5 & 95.59 & 85.92 & 56.8 & 25.06 & 71.63 \\
$\mathrm{~A}+\mathrm{C}$ & $\mathrm{n} / \mathrm{a}$ & 98.16 & 80.3 & 77.88 & 23.23 & 75.71 \\
$\mathrm{~A}+\mathrm{D}$ & $\mathrm{n} / \mathrm{a}$ & 99.29 & 81.81 & 81.14 & 22.68 & 77.77 \\
$\mathrm{~A}+\mathrm{B}+\mathrm{D}$ & 0.5 & 98.71 & 86.26 & 70.28 & 23.27 & 76.6 \\
\hline
\end{tabular}

A: Original system, B: ATR, C: Heat recycling, D: Heat insulation;

Fuel flow rate: $10 \mathrm{~L} / \mathrm{min}, \mathrm{O}_{2} / \mathrm{C}$ ratio: 0.8

Table 3. Comparison of plasma converter performance under different operating conditions

increase the amount of power generated if applied to fuel cells. From this table, the variations in hydrogen and carbon monoxide yields are significantly with the combination of water gas shifting reaction, although the methane conversion efficiency is reduced. This is because the system did not adopt an external heating source to maintain its working temperature, and water addition would induce regional endothermic reactions due to the latent heat of water vaporization. The regional endothermic reaction consequently lowers the reformate gas temperature of the system and results in a reduction in the methane conversion efficiency. Another possibility for the reduction of conversion efficiency is that methanation leads to reverse reaction and increases the selectivity of methane.

This section will focus on the comparison of the theoretical calculation of the chemical equilibrium for methane reformation. The variations between the experimental results and the calculated values are compared. A comprehensive comparison of the experimental results with the theoretical calculation of the dry analysis on the output concentration of $\mathrm{H} 2+\mathrm{CO}$ is shown in Fig. 15; the values were measured under all of the parameters of the original system, the autothermal reforming reactions, and the energy conservative method. Linear regression analysis reveals that the $\mathrm{R}^{2}$ value for the concentration of syngas $\left(\mathrm{H}_{2}+\mathrm{CO}\right)$ is as high as 0.9179 , indicating that the values obtained via experiments and the values obtained from theoretical calculation are very close.

The following section discusses the effect of plasma reforming parameters (PRP) on the overall reforming performance. The purpose is to compile all of the measured results of this study and to identify the correlations within the parameters. The reforming indicators, $\mathrm{H}_{2}+\mathrm{CO}$ concentration and thermal efficiency will be discussed. Fig. 16 shows the effect of the first plasma reforming parameters (PRP1) on the concentration of $\mathrm{H}_{2}+\mathrm{CO}$. PRP1 is comprised of the methane molar flow rate, oxygen-carbon molar ratio, and the methane conversion efficiency; these reforming parameters are also closely associated with the concentration of $\mathrm{H}_{2}+\mathrm{CO}$. The $\mathrm{R}^{2}$ value of the quadratic regression at different operating conditions can be as high as 0.9104. It is also shown in Fig. 16 that an increase of PRP1 signifies a greater methane flow rate, a more appropriate $\mathrm{O}_{2} / \mathrm{C}$ ratio, and a better methane conversion efficiency; and the concentration of $\mathrm{H}_{2}+\mathrm{CO}$ first increases as PRP1 increases, and then subsequently decreases. Thus, the data imply that there is an upper limit for the $\mathrm{O}_{2} / \mathrm{C}$ ratio in this system, and exceeding this limit would lead to a decrease in hydrogen concentration due to the oxidization of $\mathrm{H}_{2}+\mathrm{CO}$ into $\mathrm{H}_{2} \mathrm{O}$ and $\mathrm{CO}_{2}$ by excess oxygen. 


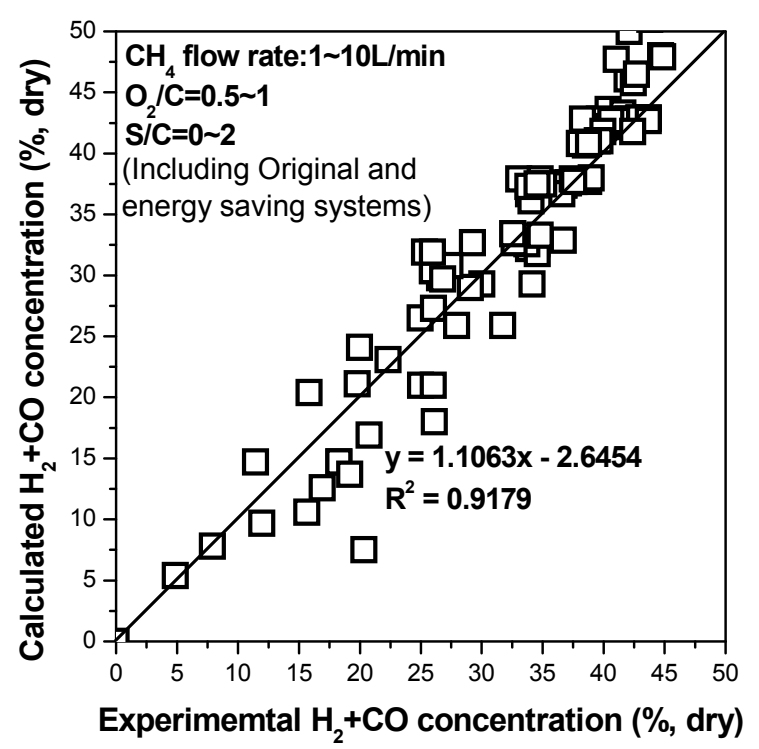

Fig. 15. Comparison of theoretical calculations and the experimental results of methane at different operational parameters

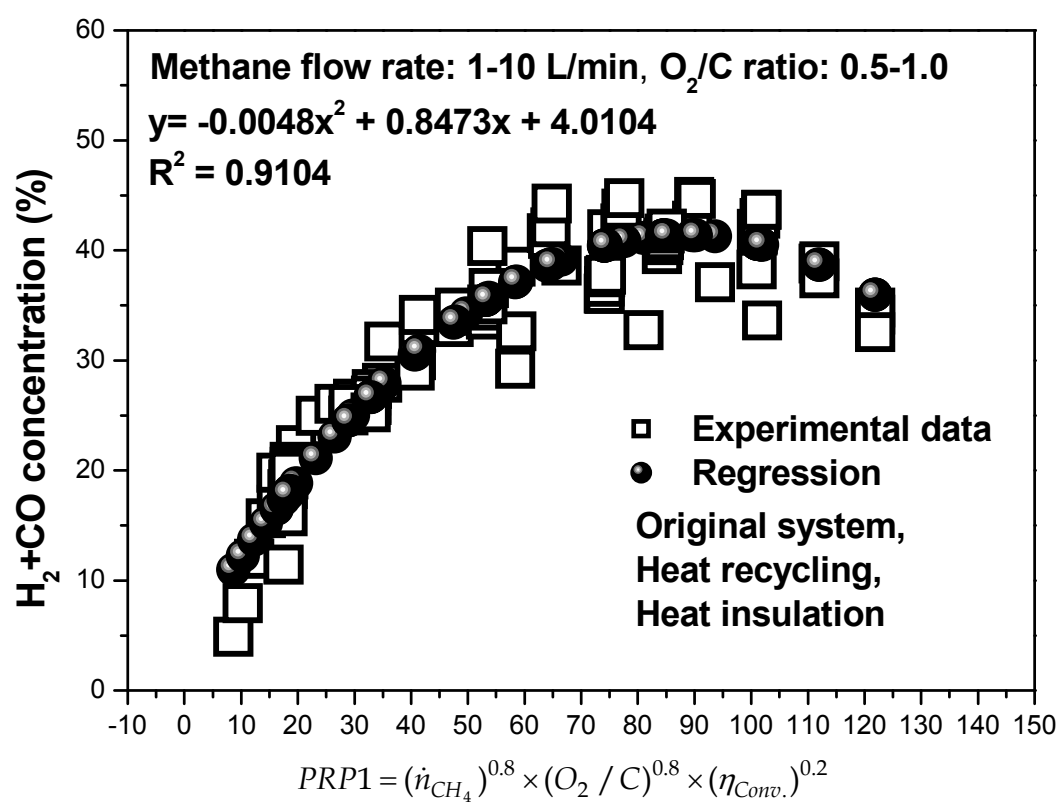

Fig. 16. The effect of the $1^{\text {st }}$ plasma reforming parameters (PRP1) on $\mathrm{H}_{2}+\mathrm{CO}$ concentration under different operation conditions 
Fig. 17 shows the effect of the second plasma reforming parameters (PRP2) on thermal efficiency under the operational parameter settings. The plasma reforming parameters are comprised of the methane molar flow rate, the oxygen-carbon molar ratio, the reformate gas temperature, and the conversion efficiency of methane. The effects of these plasma reforming parameters on thermal efficiency are obvious, and the $\mathrm{R}^{2}$ value of the regression calculation is as high as 0.9284 . Of all the second plasma reforming parameters, PRP2 corresponds to higher thermal efficiency with higher methane flow rate, greater oxygencarbon ratio, and a higher reformate gas temperature. Under these parameters, the catalysts are able to work at an appropriate temperature, and to improve the yield of hydrogen and carbon monoxide in the reforming. As the methane conversion efficiency increases, so does the overall energy utilization efficiency; the total thermal efficiency shows a logarithmic increase as PRP2 increases.

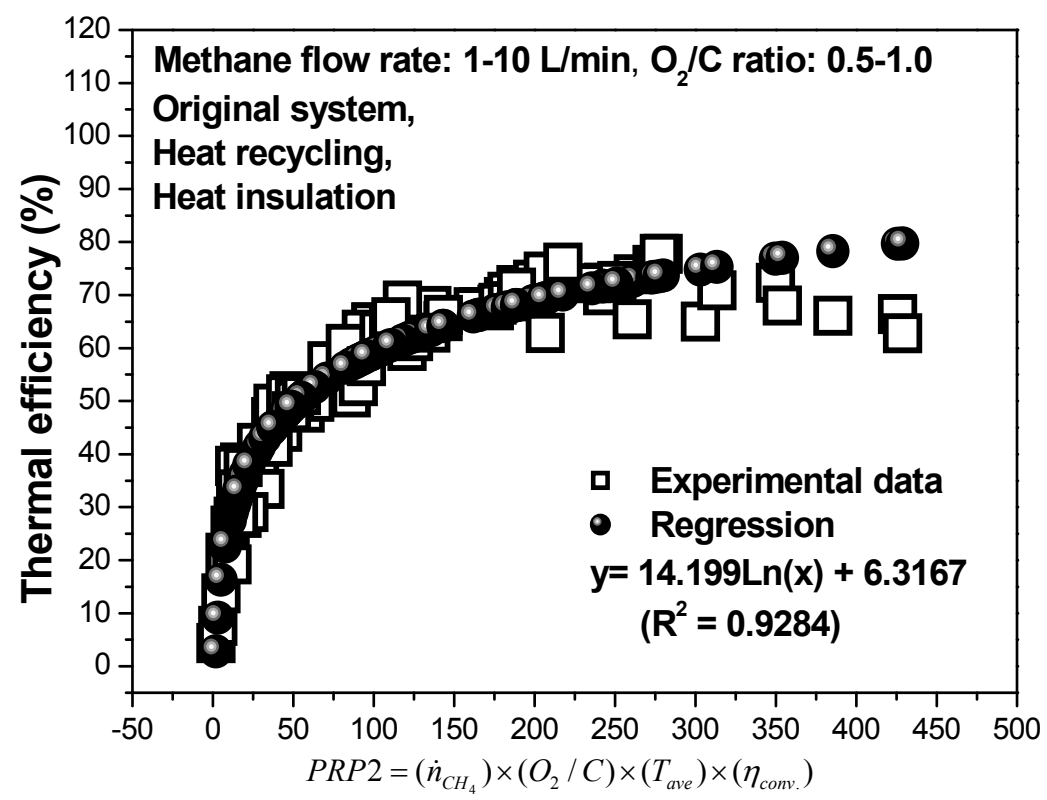

Fig. 17. The effect of the $2^{\text {nd }}$ plasma reforming parameters (PRP2) on the total thermal efficiency under different operating conditions

\subsection{A preliminary study on engine with hydrogen-rich gas as auxiliary fuel}

The following section introduces the results of the preliminary study using hydrogen-rich gas as an auxiliary fuel for a $125 \mathrm{cc} 4$-stroke motorcycle engine. The specifications of the engine used in this experiment are shown in Table 4. Hydrogen-rich gas was supplied from different gas tanks at specific ratios; the gas mixture was directed into the engine as fuel. The performance and the pollutant emissions of the engine were measured to improve the parameters for the designing of the plasma fuel reformer in the future. Because the reformer of this study reforms gas via a partial oxidation reforming approach, the composition of the reformate gas is diverse. The typical gases in the reformate products are hydrogen, carbon 


\begin{tabular}{|c|c|c|c|}
\hline Engine type & \multicolumn{3}{|c|}{ Air cooled single cylinder 4-stroke engine } \\
\hline Bore & \multicolumn{3}{|c|}{$52.4 \mathrm{~mm}$} \\
\hline Stroke & \multicolumn{3}{|c|}{$57.8 \mathrm{~mm}$} \\
\hline Displacement & \multicolumn{3}{|c|}{$124 \mathrm{~cm}^{3}$} \\
\hline Compression ratio & \multicolumn{3}{|c|}{$9.2: 1$} \\
\hline Compression pressure & \multicolumn{3}{|c|}{$12 / 570\left(\mathrm{~kg} / \mathrm{cm}^{2} / \mathrm{rpm}\right)$} \\
\hline Fuel supply system & \multicolumn{3}{|c|}{ CV type carburetor } \\
\hline Intake valve open & 0० BTDC & Intake valve close & $25^{\circ} \mathrm{ABDC}$ \\
\hline Exhaust valve open & $33^{\circ} \mathrm{BBDC}$ & Exhaust valve close & 0\% ATDC \\
\hline Fuel & \multicolumn{3}{|c|}{ Unleaded gasoline \#92 with hydrogen-rich gas } \\
\hline
\end{tabular}

Table 4 . The specifications of the motorcycle engine

monoxide, carbon dioxide, and nitrogen; thus, this experiment was carried out by supplying the mixture of these four gases as added fuel.

Both $\mathrm{H}_{2}$ and $\mathrm{CO}$ have relatively high heating values and can be used as fuel for running engines. Additionally, hydrogen has a high flame speed, and is favorable for assisting combustion. In contrast, although $\mathrm{CO}_{2}$ and $\mathrm{N}_{2}$ do not provide heating value, they could be used for exhaust gas recirculation (EGR), and could effectively lower the combustion temperature to impede the formation of NOx. Fig. 18 shows the appropriate operating range of hydrogen-rich gas at various levels of throttle openings and engine speeds. The left panel
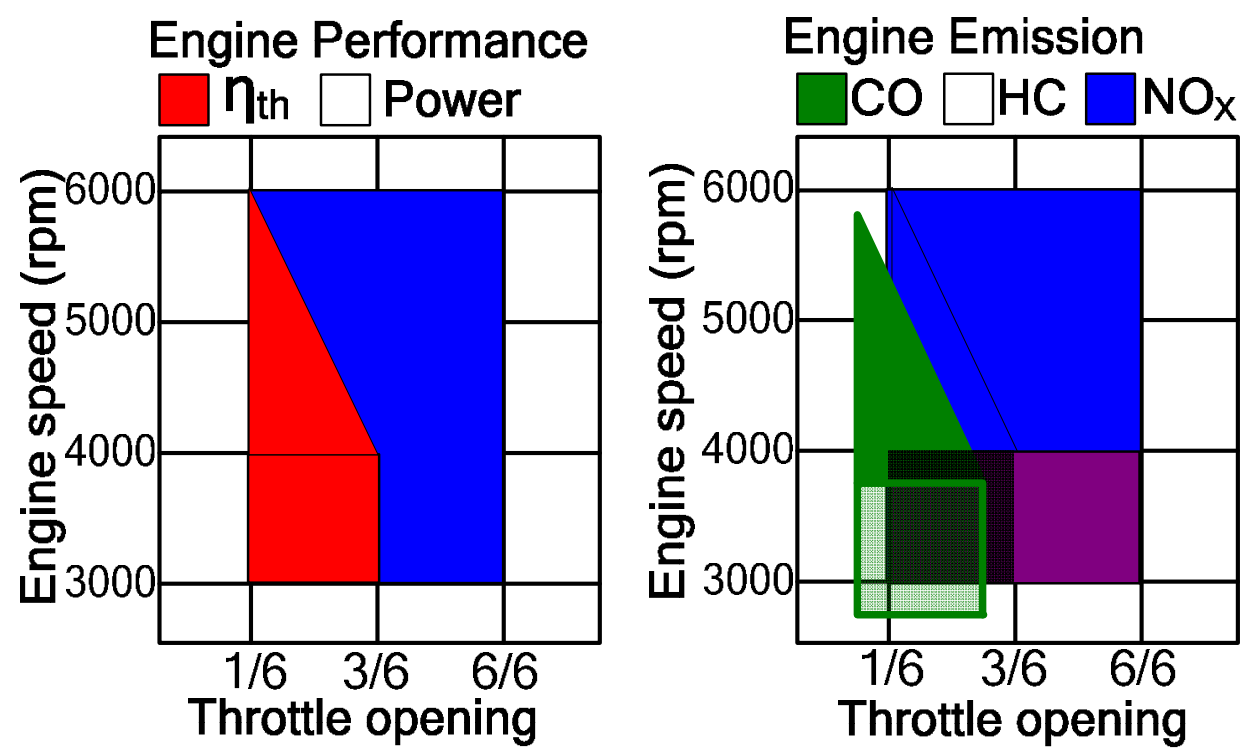

Fig. 18. Appropriate operating range of throttle openings and engine speeds by adding hydrogen-rich gas as an auxiliary fuel 
shows the engine performance, and includes thermal efficiency (shown in red), and the output horsepower (shown in blue). The right panel shows the comparison of CO (green), HC (purple), and NOx (blue) emissions. The results shown in this figure indicate that engine performance and exhaust emissions could be improved simultaneously by adding an appropriate amount of hydrogen-rich gas; that is, hydrogen-rich gas has the characteristics of assisting and impeding combustion. The output horsepower can be improved at any level of throttle opening and engine speed; in contrast to the thermal efficiency of the engine, which has better result only at low throttle opening. It could be caused by the lower ratio of $\left[\left(\mathrm{H}_{2}+\mathrm{CO}\right) /\left(\mathrm{CO}_{2}+\mathrm{N}_{2}\right)\right]$ in hydrogen-rich gas, thus resulting in the less impact on the combustion-assisting effect in other throttle openings. For the exhaust emissions of engine, although the improvement of $\mathrm{CO}$ and $\mathrm{HC}$ are not as evident as expected, NOx was greatly improved, confirming the effect of impeding combustion. Therefore, in order to produce the appropriate composition of hydrogen-rich gas for simultaneously improving the thermal efficiency and exhaust emissions of engine, the operating parameter setting of plasma converter would be very important.

\section{Conclusions}

This study investigated the reformation of methane for hydrogen production by an energy conservative plasma fuel converter under different operation parameters and conditions. The experimental parameters include fuel flow rate, $\mathrm{O}_{2} / \mathrm{C}$ ratio, and $\mathrm{S} / \mathrm{C}$ ratio. Additionally, the operating conditions are categorized into autothermal reforming reaction and energy conserving approaches. By conducting a series of experiments, the conclusions were drawn as followed:

For methane reforming, the reforming temperature for the best hydrogen selectivity is between 600 and $700{ }^{\circ} \mathrm{C}$. By taking energy conservation approaches, the hydrogen production and the thermal efficiency of reformer are improved. Under the best parameter setting, the total thermal efficiency can be as high as $77.77 \%$ with the methane flow rate of $10 \mathrm{NL} / \mathrm{min}$ and the $\mathrm{O}_{2} / \mathrm{C}$ ratio of 0.8 . Furthermore, the hydrogen yield can be further increased to $86.26 \%$ by adding an appropriate amount of water vapor (S/C ratio of 0.5 ), and the produced hydrogen flow rate is approximate $17.25 \mathrm{NL} / \mathrm{min}$. And in the reforming process, the $\mathrm{O}_{2} / \mathrm{C}$ ratio, the fuel flow rate, the space velocity, and the reformate gas temperature have a great influence on reforming performance. As the first plasma reforming parameter (PRP1) increases, the $\mathrm{H}_{2}+\mathrm{CO}$ concentration shows a quadratic polynomial increase accordingly; and the thermal efficiency shows a logarithmic increase with the second plasma reforming parameters (PRP2). In this study, the HSC commercialized software was used for theoretical equilibrium calculation. The experimental results are very close to the value obtained through theoretical calculation. The regression coefficient $\left(\mathrm{R}^{2}\right)$ can be as high as 0.918 between the experimented and calculated $\mathrm{H}_{2}+\mathrm{CO}$ concentrations.

\section{Acknowledgments}

This study was supported by the National Science Council Research Projects (project numbers: NSC 95-2622-E-168-008-CC3, NSC 95-2221-E-168-032-MY2 \& NSC 97-2221-E-168033-MY3) and Jellys Technology Inc. 


\section{References}

Al-Janabi, H.A.S. \& Al-Baghdadi, M.A.S. (1999). A prediction study of the effect of hydrogen blending on the performance and pollutions emission of a four stroke spark ignition engine. International Journal of Hydrogen Energy, Vol.24, No.4, (April 1999), pp. 363-375, ISSN 0360-3199

Ayabe, S., Omoto, H., Utaka, T., Kikuchi, R., Sasaki, K., Teraoka, Y. \& Eguchi, K. (2003). Catalytic autothermal reforming of methane and propane over supported metal catalysts. Applied Catalysis A: General, Vol.241, No.1-2, (February 2003), pp. 261-269, ISSN 0926-860X

Bromberg, L., Cohn, D. R. \& Rabinovich, A. (1997). Plasma reformer-fuel cell system for decentralized power applications. International Journal of Hydrogen Energy, Vol.22, No.1, (January 1997), pp. 83-94, ISSN 0360-3199

Bromberg, L., Cohn, D.R., Rabinovich, A., Surma, J.E. \& Virden, J. (1999a). Compact plasmatron -boosted hydrogen generation technology for vehicular applications. International Journal of Hydrogen Energy, Vol.24, No.4, (April 1999), pp. 341-350, ISSN 0360-3199

Bromberg, L., Cohn, D. R., Rabinovich, A. \& Alexeev, N. (1999b). Plasma catalytic reforming of methane. International Journal of Hydrogen Energy, Vol.24, No.12, (December 1999), pp.1131-1137, ISSN 0360-3199

Bromberg, L., Cohn, D.R., Rabinovich, A., Alexeev, N., Samokhin, A., Ramprasad, R. \& Tamhankar, S. (2000). System optimization and cost analysis of plasma catalytic reforming of natural gas. International Journal of Hydrogen Energy, Vol.25, No.12, (December 2000), pp. 1157-1161, ISSN 0360-3199

Bromberg, L., Cohn, D. R., Rabinovich, A. \& Heywood, J.B. (2001). Emissions reductions using hydrogen from plasmatron fuel converters. International Journal of Hydrogen Energy, Vol.26, No.10, (October 2001), pp. 1115-1121, ISSN 0360-3199

Cohn, D.R., Rabinovich, A. \& Titus, C.H. (1996). Onboard plasmatron generation of hydrogen for extremely low emission vehicle with internal combustion engine. International Journal of Vehicle Design, Vol.17, No.5-6, (1996), pp. 550-561, ISSN 14775360

Futamura, S., Kabashima, H., Annadurai, G. (2006). Roles of $\mathrm{CO}_{2}$ and $\mathrm{H}_{2} \mathrm{O}$ as oxidants in the plasma reforming of aliphatic hydrocarbons. Catalysis Today, Vol. 115, No.1-4, (June 2006), pp. 211-226, ISSN 0920-5861

Horng, R. F., Chang, Y. P. \& Chung, C. L. (2006a). Carbon deposit growth on the electrodes of a plasma converter in the generation of hydrogen from methane. International Journal of Hydrogen Energy, Vol.31, No.14, (November 2006a), pp. 2040-2051, ISSN 0360-3199

Horng, R.F., Chang, Y.P. \& Wu, S.C. (2006b). Investigation on the production of hydrogenrich gas in a plasma converter for motorcycle applications. Energy Conversion and Management, Vol.47, No.15-16, (September 2006b), pp. 2155-2166, ISSN 0196-8904

Horng, R. F., Chang, Y. P., Huang, H. H. \& Lai, M. P. (2007). A study of the hydrogen production from a small plasma converter. Fuel, Vol.86, No.1-2, (January 2007), pp. 81-89, ISSN 0016-2361

Horng, R.F., Huang, H.H., Lai, M.P., Wen, C.S. \& Chiu, W.C. (2008). Characteristics of hydrogen production by a plasma-catalyst hybrid converter with energy saving 
schemes under atmospheric pressure. International Journal of Hydrogen Energy, Vol. 33, No.14, (July 2008a), pp. 3719-3727, ISSN 0360-3199

Horng, R.F., Wen, C.S., Liauh, C.T., Chao, Y. \& Huang, C.T. (2008). Driving characteristics of a motorcycle fuelled with hydrogen-rich gas produced by an onboard plasma reformer. International Journal of Hydrogen Energy, Vol. 33, No.24, (December 2008b), pp. 7619-7629, ISSN 0360-3199

Horng, R.F., Lai, M.P., Huang, H.H. \& Chang, Y.P. (2009). Reforming performance of a plasma-catalyst hybrid converter using low carbon fuels. Energy Conversion and Management, Vol. 50, No.10, (October 2009), pp. 2632-2637, ISSN 0196-8904

Jamal, Y., Wagner T. \& Wyszynski, M. L. (1996). Exhaust gas reforming of gasoline at moderate temperature. International Journal of Hydrogen Energy, Vol.21, No.6, (June 1996), pp. 507-519, ISSN 0360-3199

Lutz, A.E., Bradshaw, R.W., Keller, J.O. \& Witmer, D.E. (2003). Thermodynamic analysis of hydrogen production by steam reforming. International Journal of Hydrogen Energy, Vol.28, No.2, (February 2003), pp. 159-167, ISSN 0360-3199

Lutz, A.E., Bradshaw, R.W., Bromberg, L. \& Rabinovich, A. (2004). Thermodynamic analysis of hydrogen production by partial oxidation reforming. International Journal of Hydrogen Energy, Vol.29, No.8, (July 2004), pp. 809-816, ISSN 0360-3199

Ma, F., Wang, Y., Liu, H., Li, Y., Wang, J. \& Zhao, S. (2007). Experimental study on thermal efficiency and emission characteristics of a lean burn hydrogen enriched natural gas engine. International Journal of Hydrogen Energy, Vol.32, No.18 (December 2007), pp. 5067-5075, ISSN 0360-3199

Maruoka, N., Sato, K., Yagi, J. \& Akiyama, T. (2002). Development of PCM for recovering high temperature waste heat and utilization for producing hydrogen by reforming reaction of methane. ISIJ international, Vol.42, No.2, (May 2002), pp. 215-219, ISSN 0915-1559

Maruoka, N., Purwanto, H. \& Akiyama, T. (2010). Exergy analysis of methane steam reformer utilizing steelmaking waste heat. ISIJ international, Vol.50, No. 9, (September 2010), pp. 1311-1318, ISSN 1347-5460

Mohammadi, A., Shioji, M., Nakai, Y., Ishikura, W. \& Tabo, E. (2007). Performance and combustion characteristics of a direct injection SI hydrogen engine. International Journal of Hydrogen Energy, Vo.32, No.2, (February 2007), pp. 296-304, ISSN 03603199

Nozaki, T \& Okazaki, K. (2005). Non-equilibrium reaction fields created by atmospheric pressure plasmas and application to advanced utilization of natural gas resource. Journal of the Japan Institute of Energy, Vol.84, No.6, (June 2005), pp. 462-467, ISSN 0916-8753

Outokumpu. (2002). Chemical reaction and equilibrium software with extensive thermochemical database. HSC Chemistry® for Windows, Version 5.1, ISBN 9529507-08-9

Petitpas, G., Rollier, J.D., Darmon, A., Gonzalez-Aguilar, J., Metkemeijer, R. \& Fulcheri, L. (2007). Review-a comparative study of non-thermal plasma assisted reforming technologies. International Journal of Hydrogen Energy, Vol. 32, No.14, (September 2007), pp. 2848-2867, ISSN 0360-3199

Peucheret, S., Wyszynski, M.L., Lehrle, R.S., Golunski, S. \& Xu, H. (2005). Use of catalytic reforming to aid natural gas HCCI combustion in engines: experimental and 
modelling results of open-loop fuel reforming. International Journal Hydrogen Energy, Vol.30, No.15, (December 2005), pp. 1583-1594, ISSN 0360-3199

Pietruszka, B. \& Heintze, M. (2004). Methane conversion at low temperature: the combined application of catalysis and non-equilibrium plasma. Catalysis Today, Vol.90, No.12, (June 2004), pp. 151-158, ISSN 0920-5861

Rabinovich, A., Cohn, D. R. \& Bromberg, L. Plasmatron internal combustion engine system for vehicle pollution reduction. International Journal of Vehicle Design, Vol.15, No.3-5, (November 1994), pp. 234-242, ISSN 1477-5360

Seo, Y.T., Seo, D.J., Jeong, J.H. \& Yoon, W.L. (2006). Design of an integrated fuel processor for residential PEMFCs applications. Journal of Power Sources, Vol.160, No.1, (September 2006), pp. 505-509, ISSN 0378-7753

Shudo, T. (2006). An HCCI combustion engine system using on-board reformed gases of methanol with waste heat recovery: ignition control by hydrogen. International Journal of Vehicle Design, Vol.41, No.1-4, (2006), pp. 206-226, ISSN 1477-5360

Sobacchi, M.G., Saveliev, A.V., Fridman, A.A., Kennedy, L.A., Ahmed, S. \& Krause, T. (2002). Experimental assessment of a combined plasma/catalytic system for hydrogen production via partial oxidation of hydrocarbon fuels. International Journal of Hydrogen Energy, Vol.27, No.6, (June 2002), pp. 635-642, ISSN 0360-3199

Song, C. (2006). Global challenges and strategies for control, conversion and utilization of $\mathrm{CO}_{2}$ for sustainable development involving energy, catalysis, adsorption and chemical processing. Catalysis Today, Vol.115, No.1-4, (June 2006), pp. 2-32, ISSN 0920-5861

Verhelst, S. \& Sierens, R. (2001). Aspects concerning the optimisation of a hydrogen fueled engine. International Journal of Hydrogen Energy, Vol.26, No.9, (September 2001), pp. 981-985, ISSN 0360-3199

Zheng, M., Reader, G.T. \& Hawley, J.G. (2004). Diesel engine exhaust gas recirculation-a review on advanced and novel concepts. Energy Conversion and Management, Vol. 45, No.6, (April 2004), pp. 883-900, ISSN 0196-8904 


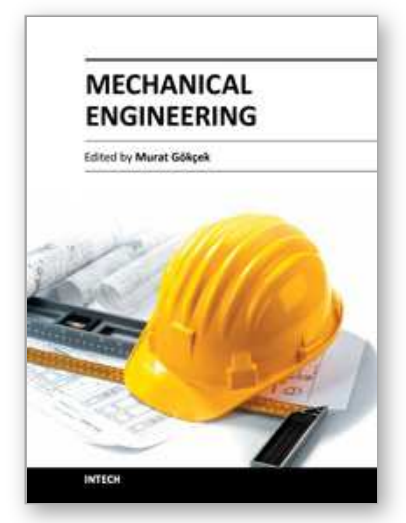

\author{
Mechanical Engineering \\ Edited by Dr. Murat Gokcek
}

ISBN 978-953-51-0505-3

Hard cover, 670 pages

Publisher InTech

Published online 11, April, 2012

Published in print edition April, 2012

The book substantially offers the latest progresses about the important topics of the "Mechanical Engineering" to readers. It includes twenty-eight excellent studies prepared using state-of-art methodologies by professional researchers from different countries. The sections in the book comprise of the following titles: power transmission system, manufacturing processes and system analysis, thermo-fluid systems, simulations and computer applications, and new approaches in mechanical engineering education and organization systems.

\title{
How to reference
}

In order to correctly reference this scholarly work, feel free to copy and paste the following:

Rong-Fang Horng and Ming-Pin Lai (2012). Waste Heat Recycling for Fuel Reforming, Mechanical Engineering, Dr. Murat Gokcek (Ed.), ISBN: 978-953-51-0505-3, InTech, Available from:

http://www.intechopen.com/books/mechanical-engineering/waste-heat-recycling-for-fuel-reforming

\section{INTECH}

open science | open minds

\author{
InTech Europe \\ University Campus STeP Ri \\ Slavka Krautzeka 83/A \\ 51000 Rijeka, Croatia \\ Phone: +385 (51) 770447 \\ Fax: +385 (51) 686166 \\ www.intechopen.com
}

\author{
InTech China \\ Unit 405, Office Block, Hotel Equatorial Shanghai \\ No.65, Yan An Road (West), Shanghai, 200040, China \\ 中国上海市延安西路65号上海国际贵都大饭店办公楼405单元 \\ Phone: +86-21-62489820 \\ Fax: +86-21-62489821
}


(C) 2012 The Author(s). Licensee IntechOpen. This is an open access article distributed under the terms of the Creative Commons Attribution 3.0 License, which permits unrestricted use, distribution, and reproduction in any medium, provided the original work is properly cited. 